\title{
The Joint Impact of Labour Policies and the "Great Recession" on Unemployment in Europe
}

Forthcoming, Economic Systems

\author{
Silvia Dal Bianco (correspondingauthor) \\ LondonMetropolitanUniversity \\ Old Castle Street, E1 7NT, London \\ E-mail: s.dalbianco@londonmet.ac.uk \\ Randolph L. Bruno \\ University College London, \\ IZA and \\ Rodolfo De Benedetti Foundation \\ E-mail: randolph.bruno@ucl.ac.uk \\ Marcello Signorelli \\ University of Perugia \\ E-mail: marcello.signorelli@unipg.it
}

\begin{abstract}
The paper consists in an empirical analysis of the separate as well as joint impacts on total and youth unemployment of indicators of labour market policies, on the one hand, and the financial crisis associated with the "Great Recession", on the other. In particular, we investigate labour market data in the past two decades for the Enlarged Europe and we adopt a variable accounting for the idiosyncratic-severity shock of the crisis. This time-varying and country-specific crisis variable enables us to test empirically and in a novel way the joint impact of labour market policies and the economic crisis on labour market dynamics even when accounting for common macro shocks.
\end{abstract}

JEL Classification: J65, O52, C23

Keywords: unemployment, youth unemployment, crisis, labour market policies

Earlier versions of this paper have been presented at the EACES-ETUI Workshop on "Comparative Perspectives on the European Labour Markets" (7 March 2014, Brussels) and accepted for presentation at the 13th EACES biannual Conference (September 4-6 2014, Budapest). We thank for their useful comments an anonymous referee, Saul Estrin and Maria Luigia Segnana; the usual disclaimer applies.

\section{Introduction and Motivation}


A large body of literature investigates the impact of labour market institutions and policies, such as active and passive labour market policies, on unemployment. Moreover, a growing number of scholars have more recently focused on the impact of economic and financial crises on labour market dynamics in general. However, there are still few studies that address the question of the complex joint impact on unemployment of both labour market policies and the financial and economic crisis occurring during the "Great Recession".

Our empirical analysis and econometrics exercise seek to determine the role of labour market policies in shaping the relation between the financial and economic crisis and (total and youth) unemployment. To this end, we calculate the effect of the last crisis on unemployment for different types and levels of labour market policies, and we also consider the interaction among proxies for the crisis and labour market policies.

The paper is organised as follows. Section two provides an extensive literature review on the determinants of unemployment, as well as on the relationship between (youth) unemployment, on the one hand, and labour market policies and financial crises on the other. Section three presents our testable hypotheses and empirical strategy. Section four describes the data and provides details on the calculations of labour market policy indicators, as well as of the severity of the last economic and financial crisis. Section five develops the empirical analysis and sets out the empirical model's results by looking at a longitudinal panel of 30 European countries in the past two decades. Finally, section six concludes with some policy implications.

\section{Literature Review}

There is a huge body of theoretical and empirical literature on the determinants of total and youth unemployment differences across countries and regions, and their dynamics. The best-known unemployment determinants are related to general macroeconomic conditions, such as GDP growth and productivity dynamics, according to Okun's law (see Lee, 2000; Solow, 2000; and IMF, 2010; for empirical applications). In this section, we concentrate on more specific unemployment determinants of crucial interest for this paper, namely: (i) 
institutions and policies, (ii) institutions and shocks, (iii) the impact of the past and the most recent economic and financial crisis.

\subsection{Labour Institutions and Policies}

Since the seminal OECD Jobs Study (1994), the so-called "Eurosclerosis" phenomenon - defined as the weak employment performance of Europe - has been related to institutional variables. According to the institutional economics tradition, the labour market (and market only) institutions comprise: labour taxes, unemployment benefits (amount, duration, and the replacement ratio) as key indicators of so-called passive labour market policies, the degree of unionisation (union density and union coverage), the structure of collective bargaining (degree of coordination and/or centralisation), Employment Protection Legislation (EPL), the incidence of temporary and part-time contracts, active labour market policies (ALMP), the liberalisation of product markets, housing policies, and many other factors besides. ${ }^{1}$

Among the empirical works in this field, the OECD report (2006) highlights the statistical significance of tax wedges in explaining high unemployment rates together with generous (unemployment) benefit systems and stringent (anti-competitive) product market regulations, ${ }^{2}$ while the degree of coordination in collective bargaining appears to improve labour market performance. As far as the EPL is concerned (e.g. tight firing regulations in Southern European countries), the available evidence is mixed, although the majority of studies find a positive relation between EPL and the unemployment rate (e.g. Heckman and Pagés, 2003). Turning to product market regulations, "economic freedom" affects the labour market favourably both by improving the functioning of such markets (direct effect) and by stimulating economic growth (indirect effect). ${ }^{3}$

\footnotetext{
${ }^{1}$ Nickell (1997) proposes measures for eight "labour market institutions" and he finds that in general high unemployment is associated with welfare systems that do not put pressure on the unemployed to search for and accept work offers, with high taxes on labour and also with no co-ordination in wage bargaining. The key role of ALMP, together with unemployment benefits, in explanation of changes in employment and unemployment rates is confirmed by the estimations of Destefanis and Mastromatteo (2010), while Betcherman et al. (2004) observe that only some active labour market policies have a positive impact on labour market performance. As for investigations at both national and regional levels in the European context, see Perugini and Signorelli (1994 and 1997).

${ }^{2}$ Hence, product market reforms can reduce unemployment rates (Fiori et al., 2008).

${ }^{3}$ In some empirical studies, an "index of the economic freedom of the world" has been used (Feldmann, 2010), but more particular "freedoms" have additionally been investigated: the size of the government, the rule of law
} 
More generally, changes in policies and institutions, together with changes in the output gap, are estimated to explain $74 \%$ of the cross-country variance in the unemployment changes observed for the period 1982-2003 (OECD, 2006). Finally, several authors have investigated the key role of differences in "welfare systems" for labour market performance (e.g. Boeri, 2002; Bruno and Rovelli, 2010; Esping-Andersen, 1996 and 1999). ${ }^{4}$ In particular, Bruno and Rovelli (2010) find that higher employment rates are positively associated with active labour market policies and negatively with institutions and policies determining rigidity in the labour market; they also find that the relation between Active Labour Market Policies (i.e. ALMP) and employment levels is non-monotonic and that it is conditional on the informal institutions of the different countries.

\subsection{Institutions and Shocks}

There is an innovative literature on the interaction between institutions and shocks. Blanchard and Wolfers (2000) highlight the fact that adverse shocks can explain the general increase in unemployment in the European context vis-àvis the United States, while differences in institutions can explain differences in performance across European countries. According to these authors, labour market institutions can shape the effects of shocks by affecting their impact on unemployment and by affecting the persistence of unemployment precisely in response to shocks. ${ }^{5}$ For example, if institutions filter the effect that higher unemployment can exert on the labour market by reducing wages, they will increase the persistence of unemployment in response to shocks (see also Layard and Nickell, 1987). Sargent and Ljundqvist (1995) investigated the effect of unemployment insurance rules on the relationship between shocks (turbulence) and equilibrium unemployment. Mortensen and Pissarides (2001) analysed the effect of unemployment insurance and EPL on the relationship between relative demand shifts and equilibrium unemployment. Finally, not only is the impact of

and security of property rights, the liberalisation of international trade, and flexible regulations. Moreover, such reforms are mutually reinforcing, justifying comprehensive reform programmes rather than separate labour market reforms, and they may interact with macroeconomic conditions and shocks (see next sub-section). Brandt et al. (2005) used a synthetic index of the intensity of "reform policies" and found that OECD-inspired reforms improve labour-market performance with a five-year lag (see also Bassanini and Duval, 2006), signalling the medium to long run effects of such reforms.

4 As for the transition economies, see Bruno (2006).

${ }^{5}$ Blanchard and Summers (1987) shown that, while the permanent effect of shocks is unlikely, institutions can lead to high persistence. 
macroeconomic shocks amplified by the existence of certain policies and institutions, but the persistence of the shocks is increased because of long-run effects on labour demand (Marelli et al., 2013).

\subsection{Past and Most Recent Financial Crises}

A growing number of studies have tried to estimate the effects on total and youth unemployment of the last financial crisis and the so-called "Great Recession” (for example, Brada and Signorelli, 2012; Furceri and Mourougane, 2009; World Bank, 2010; ILO, 2010 and 2012; O’Higgins, 2012; Marelli, Patuelli and Signorelli, 2012, Boeri et al, 2013) ${ }^{6}$.

Following the recent review by Boeri et al. (2013), the literature envisages a number of links between financial and labour markets: the risk adjustment effect (Hart, 1983; Greenwald and Stiglitz, 1987); the quasi-fixed investment effect of labour demand (Oi, 1962; Farmer, 1985); the stickiness of the bankborrower relationship in the presence of asymmetric information (Holmstrom and Tirole, 1997; Wasmer and Weil, 2004); the relationship between firm leverage and labour market flexibility (Monacelli et al, 2011 among many others) and, finally, the link between financial frictions and search-based unemployment in the event of a financial shock.

The overall lesson that can be drawn from these studies is that the labour market is hugely affected by the financial market's dynamics and that there may be large employment-unemployment variations during economic recessions caused by financial crises.

Turning to the findings on the youth unemployment rate during financial crises, the established literature finds that the impact of financial distress on the youth unemployment rate is larger than that on the adult unemployment rate. ${ }^{7}$ This is because, in times of crisis, the structural problems characterising the transition from school to work are exacerbated. For example, labour demand is typically lower, school-leavers compete with more jobseekers for fewer vacancies,

\footnotetext{
6 As for the performance of the "flexicurity system" in crisis time, see Auer (2010), Boeri et al. (2012), Jørgensen (2010), Lyhne Ibsen (2010); while Signorelli et al. (2012) invesigated the impact of financial crises on female labour.

${ }^{7}$ The huge literature investigating the structural reasons determining, in several countries, a much higher youth unemployment rate with respect to adult rate is not considered here (for a survey, see Pastore, 2014); see also OECD (2005), Carmeci and Mauro (2003), Bernal-Verdugo et al. (2012), Feldmann (2010), Caroleo and Pastore (2007), Quintini and Manfredi (2009) and Ryan (2001).
} 
and unemployment may become structural. This may be the case in some Eurozone countries, which have been affected by a very long (and possibly double-dip) recession where young people are at risk of becoming a "lost generation" (Scarpetta et al. 2010). Furthermore, O'Higgins (2011 and 2012) highlights that the key problem is not only that young people are more vulnerable to crises but also that these effects are likely to be more long-lasting for youngsters than for adults. ${ }^{8}$ Moreover, the size of the group of "youth left behind" is generally larger than the Youth Unemployment Rate indicates, and it can be proxied by the number of young people who are neither employed nor in education or training (NEETs) (O’Higgins, 2012; Scarpetta et al., 2010).

There are also papers that have sought to gain insights from studying the impact of past financial crises on unemployment. ${ }^{9}$ For example, Verick (2009), in order better to investigate the impact of the last crisis (especially on young men and women), analyses the effects on unemployment of the past "Big 5 Crises" (Spain 1977, Norway 1987, Finland 1991, Sweden 1991 and Japan 1992). His analysis confirms that young people are hit the hardest and that the negative impact persists long after the economy has started growing again (hysteresis effect, see also Blanchard and Summers, 1987). Finally, Choudhry et al. (2012) find that the impact of crises on the youth unemployment rate is significant and robust: youth unemployment increases until five years after a financial crisis, with the largest effects in the second and third years.

\section{Testable Hypotheses and Empirical Strategy}

We formulated the following hypotheses and we tested them via a longitudinal panel data analysis:

1) labour market policies exert an impact on the level of (total and youth) unemployment in Europe, since ALMP (vis-à-vis PLMP) is more or less suitable for coping with external shocks in different countries;

2) the country-specific severity of the crisis will be a determinant of the longlasting effect of the crises on (total and youth) unemployment;

\footnotetext{
${ }^{8}$ Long periods of unemployment erode the skills of young workers, reduce their employability, cause a permanent loss of human capital, and make unemployment persistent.

${ }^{9}$ Signorelli et al. (2012) investigated the gender-specific effect of past financial crises.
} 
3) the severity of the crisis will moderate the impact of the labour market policies (and conversely the labour market policies will moderate the impact of the severity of the crisis) on (total and youth) unemployment.

In our empirical exercise, we considered a wide range of labour market policies, at both the aggregate and disaggregated levels. Thus, following the work of Algan and Cahuc (2009), we were able to obtain some conclusive results on the dichotomy between "active" and "passive" labour market policies. In particular, we expected to find that, ceteris paribus, high expenditure on active labour market policies enhances labour productivity and will thus help to restrain unemployment increase in the case of adverse economic shocks. Conversely, high expenditure on passive labour market policies should increase the unemployment rate, and this is particularly true in the case of a crisis. This is because, as documented by Bruno and Rovelli (2010), in the presence of generous passive labour market policies, it is likely that a self-reinforcing and perverse cycle between moral hazard behaviour and scarce job search will arise.

As in Blanchard and Wolfers (2000), Nickell et al. (2005) and Bruno, and Rovelli (2010), we estimated a longitudinal panel model on the relationship between the unemployment rate $^{10}$ and labour market policies by including a full set of country ${ }^{11}$ and year dummies. This was to ensure that the estimated coefficients on the labour market policy variables were not distorted by either time-invariant omitted variables at the country level or by common macro shocks. ${ }^{1213}$

Formally, our estimable equations were:

$$
\text { unrate }_{i t}=\beta_{0}+\beta_{1} \text { Policy }_{i t}+\beta_{2} \text { Crisis }_{i t}+\beta_{3}\left(\text { Policy }^{*} \text { Crisis }_{i t}+\mu_{i}+\tau_{t}+\varepsilon_{i t}\right.
$$

\footnotetext{
${ }^{10}$ Ideally, we could also analyse the impact of the very same independent variables on employment. However, our focus is the opportunity cost of being employed when policies for the unemployed are particularly generous: hence the focus on the latter - unemployed - instead of the former - employed.

11 Employment Protection Legislation, bargaining system etc. will be mainly accounted by these countries dummies, since these variables are typically very stable over time.

${ }^{12}$ For a comparison see equation (1) page 19 and equation (2) page 25 in Blanchard Wolfers (2000).

$13 \mathrm{We}$ also ran some robustness checks for quadratic terms for both policies and the crisis instead of the interaction term, new and old member states and pre and post crises regressions. These results are available upon request. We thank an anonymous referee for suggesting these further robustness checks.
} 
where 'unrate' is the unemployment rate, 'Yunrate' is the youth unemployment rate, 'Policy' stands for labour market policy, 'Crisis' represents the severity of the financial crisis, 'Policy* Crisis' is the interaction term between labour market policy and crisis severity and, finally $\mu_{\mathrm{i}}$ and $\tau_{\mathrm{t}}$ represent, respectively, the country and year dummies.

The indexes $i$ and $t$ stand for countries and years. It is thus immediately apparent that the variables which we employed were both country and timespecific. This is an improvement with respect to previous studies, because it enabled us to evaluate the responsiveness of the unemployment rate to the aforementioned economic shocks by exploiting the variability in both the crosssectional and time dimensions.

Moreover, to be noted is that while the coefficients $\beta_{1}$ and $\beta_{2}$ account, respectively, for the direct impacts of labour market policies and the financial crisis (ceteris paribus) as in Hypothesis 1) and 2), $\beta 3$ serves to evaluate the joint effect of policy and crisis as in Hypothesis 3). Thus, the overall effect of labour market policies (crisis) on unemployment was calculated considering both the estimated $\beta_{1}\left(\beta_{2}\right)$ and $\beta_{3}$, where the estimated coefficients are indicated with a "hat" (i.e. ${ }^{\hat{\beta}}$ henceforth).

\section{Data and Descriptive Statistics}

In our empirical exercise we considered a total of 30 countries, the $28 \mathrm{EU}$ countries together with Norway and Island ${ }^{14}$, observed at yearly intervals in the period 1990-2012. ${ }^{15}$

Our dependent variables were the total and the youth unemployment rates. The former was defined as the number of people unemployed as a percentage of the labour force; where, following the definitions and recommendations of the International Labour Organisation, unemployed people are all persons 15 to 74 years of age (16 to 74 years in Spain, Italy and United

\footnotetext{
${ }^{14}$ The results were not affected by introduction of these two additional countries, which share some similar features with EU economies.

15 The panel was unbalanced due to some missing values; therefore the number of observations might change from one regression to another.
} 
Kingdom) not employed during the reference week, had actively sought work during the past four weeks, and were ready to begin working immediately or within two weeks. The youth unemployment rate was similarly calculated considering only people of less than 25 years of age. Unemployment rates, both total and youth (see Figures A1 and A2 in Appendix), together with labour market policies and GDP data, were sourced from Eurostat, while we referred to Laeven and Valencia (2010, 2012) when assessing the initial year of the financial crisis for each country.

Table 1 reports our main variables' summary statistics. It is important to note that in order to assess the impact of labour market policies on unemployment rates, we considered the opportunity cost of being employed with respect to being a beneficiary of a selected labour market policy. In particular, each of our 'Policy' variables was constructed as the country-year specific ratio of labour market policy entitlement per beneficiary (i.e. the amount of Euros spent on a selected labour market policy divided by the total number of beneficiaries) and the country-year specific GDP per capita, which proxies for the average wage rate. Thus, if the value of the Policy variable increases, it becomes more convenient to be a beneficiary of the labour market policy than to work; or put otherwise, the opportunity cost of being employed increases because the amount of money that the beneficiary loses, as incentives or subsidies, increases. As to its construction, the Policy variable was bounded between 0 and 1 .

Moreover, we built an original indicator that accounted for the country and time-specific severity of the idiosyncratic financial crisis. In particular, crisis severity (i.e. variable "countrysev") was calculated as the country-specific ratio of the number of quarters of negative GDP growth in one year to the total number of quarters of negative GDP growth experienced by the country in the period 2008-2012.16 This variable was thus both country-specific and time varying. Moreover, by construction, the variable ranged from 0 to 1 along the crisis period (see Figure A3 in Appendix). We adopted the severity of the crisis variables instead of the crisis itself because we wanted to separate two different phenomena:, we envisaged capturing the timing of the crisis, on the one hand, and the strength of the crisis on the other. We proceeded in two steps. The timing

\footnotetext{
${ }^{16} 2012$ is usually considered to mark the end of the financial crises for the European countries, but it was also the last year available in our database.
} 
of the crisis was drawn from the Laeven and Valencia 2010 database, meaning that the crisis variable started and ended in different years, depending on the country (see figure A3). This allowed the interaction term in the regressions to have an impact only starting (ending) in the relevant years for each country. This may be conceived as a pure crisis effect. However, there is not much variation across countries as far as the timing is concerned, and this is only part of the story. In fact we proceeded with a second step: each country was hit more or less at the same time by the crisis with different intensities. We therefore decided to re-name it 'severity' (number of negative growth quarters in the crisis time span over the total). The relevant question was whether this was sufficiently heterogeneous across countries to be justified. It turned out that it was (see figure A3), and so we trusted the use of this measure in the interaction term.

Table 1: Average labour market policies benefits per person and average opportunity cost of being employed (yearly average in Euros $€$ )

\begin{tabular}{|l|c|c|c|c|c|c|}
\hline $\begin{array}{l}\text { Sampled } \\
\text { Countries }\end{array}$ & $\begin{array}{c}\text { Total LMP } \\
\text { per } \\
\text { beficiary } \\
€\end{array}$ & $\begin{array}{c}\text { Active } \\
\text { LMP per } \\
\text { beneficiary } \\
€\end{array}$ & $\begin{array}{c}\text { Passive } \\
\text { LMP per } \\
\text { beneficiary } \\
€\end{array}$ & $\begin{array}{c}\text { Total LMP } \\
\text { opportunity } \\
\text { cost \% }\end{array}$ & $\begin{array}{c}\text { Active } \\
\text { LMP } \\
\text { opportunity } \\
\text { cost \% }\end{array}$ & $\begin{array}{c}\text { Passive } \\
\text { LMP } \\
\text { opportunity } \\
\text { cost \% }\end{array}$ \\
\hline Austria & 12042.81 & 8642.584 & 12226.8 & 0.39 & 0.28 & 0.41 \\
\hline Belgium & 8608.096 & 7596.362 & 7805.754 & 0.28 & 0.25 & 0.28 \\
\hline Bulgaria & 1170.28 & 1320.13 & 925.4853 & 0.29 & 0.32 & 0.23 \\
\hline Cyprus & 8151.734 & 6100.496 & 8290.672 & 0.39 & 0.29 & 0.40 \\
\hline Czech Rep. & 3573.498 & 3303.156 & 2285.65 & 0.28 & 0.26 & 0.19 \\
\hline Denmark & 21167.81 & 19074.66 & 19200.6 & 0.52 & 0.53 & 0.52 \\
\hline Estonia & 2768.346 & 3914.914 & 2369.294 & 0.27 & 0.42 & 0.23 \\
\hline Finland & 10536.4 & 11768.82 & 9492.728 & 0.36 & 0.40 & 0.32 \\
\hline France & 10018.21 & 8229.614 & 9654.608 & 0.37 & 0.31 & 0.36 \\
\hline Germany & 11650.27 & 10850.74 & 10396.14 & 0.43 & 0.41 & 0.39 \\
\hline Greece & 5687.169 & 6849.936 & 3647.698 & 0.28 & 0.41 & 0.21 \\
\hline Hungary & 2666.413 & 2643.831 & 2251.465 & 0.29 & 0.28 & 0.25 \\
\hline Ireland & 11677.78 & 10612.66 & 8038.793 & 0.30 & 0.31 & 0.23 \\
\hline Italy & 7757.881 & 3697.116 & 11039.02 & 0.30 & 0.15 & 0.45 \\
\hline Latvia & 2208.418 & 2812.087 & 1817.521 & 0.29 & 0.37 & 0.23 \\
\hline Lithuania & 2720.967 & 2794.734 & 1848.841 & 0.33 & 0.36 & 0.22 \\
\hline Luxembourg & 16918.48 & 10828.85 & 22821.22 & 0.25 & 0.16 & 0.38 \\
\hline Malta & 2500.975 & 2708.01 & 2026.12 & 0.17 & 0.19 & 0.14 \\
\hline Netherlands & 15973.39 & 11366.28 & 13398.72 & 0.47 & 0.37 & 0.44 \\
\hline Norway & 20334.4 & 22374.9 & 17496.5 & 0.42 & 0.44 & 0.34 \\
\hline Poland & 2635.991 & 2281.093 & 2487.38 & 0.32 & 0.28 & 0.31 \\
\hline
\end{tabular}




\begin{tabular}{|l|c|c|c|c|c|c|} 
Portugal & 5969.581 & 4373.695 & 5469.195 & 0.39 & 0.28 & 0.37 \\
\hline Romania & 1426.415 & 878.4591 & 1435.678 & 0.31 & 0.19 & 0.31 \\
\hline Slovakia & 2283.656 & 991.7724 & 3072.922 & 0.22 & 0.09 & 0.30 \\
\hline Slovenia & 5932.106 & 3674.272 & 6203.459 & 0.35 & 0.22 & 0.37 \\
\hline Spain & 5804.999 & 2321.41 & 9711.303 & 0.26 & 0.12 & 0.50 \\
\hline Sweden & 12115.88 & 13773.35 & 9118.254 & 0.37 & 0.42 & 0.29 \\
\hline $\begin{array}{l}\text { United } \\
\text { Kingdom }\end{array}$ & 10006.73 & 10839.56 & 3934.773 & 0.33 & 0.37 & 0.14 \\
\hline
\end{tabular}

\section{Empirical Results}

Table 2 analyses the labour market policies in regard to their aggregates. Set out in Column 1 is the total amount of labour policies (expressed as the opportunity cost of being employed); in Column 2 only the aggregate for Active Labour Market Policies; and in Column 3 only the aggregate for passive labour market policies. Due to the fact that our regression controlled for common time shocks (among which the crisis itself) and time invariant countries effect, there is no significant result for the relative severity of crises per se (1 st $^{\text {column}) . ~}$ However, this result of "no impact" is present in the total Active Labour Market Policies, but not in the Passive ones. In fact, the aggregate PLMP do have a significant impact on unemployment, as well as the relative crises and their interaction. In section 5.1 we propose a detailed interpretation of these results (section "Non-monotonous Effects" below).

Table 2: Unemployment rate, Aggregate Policies and Crisis 


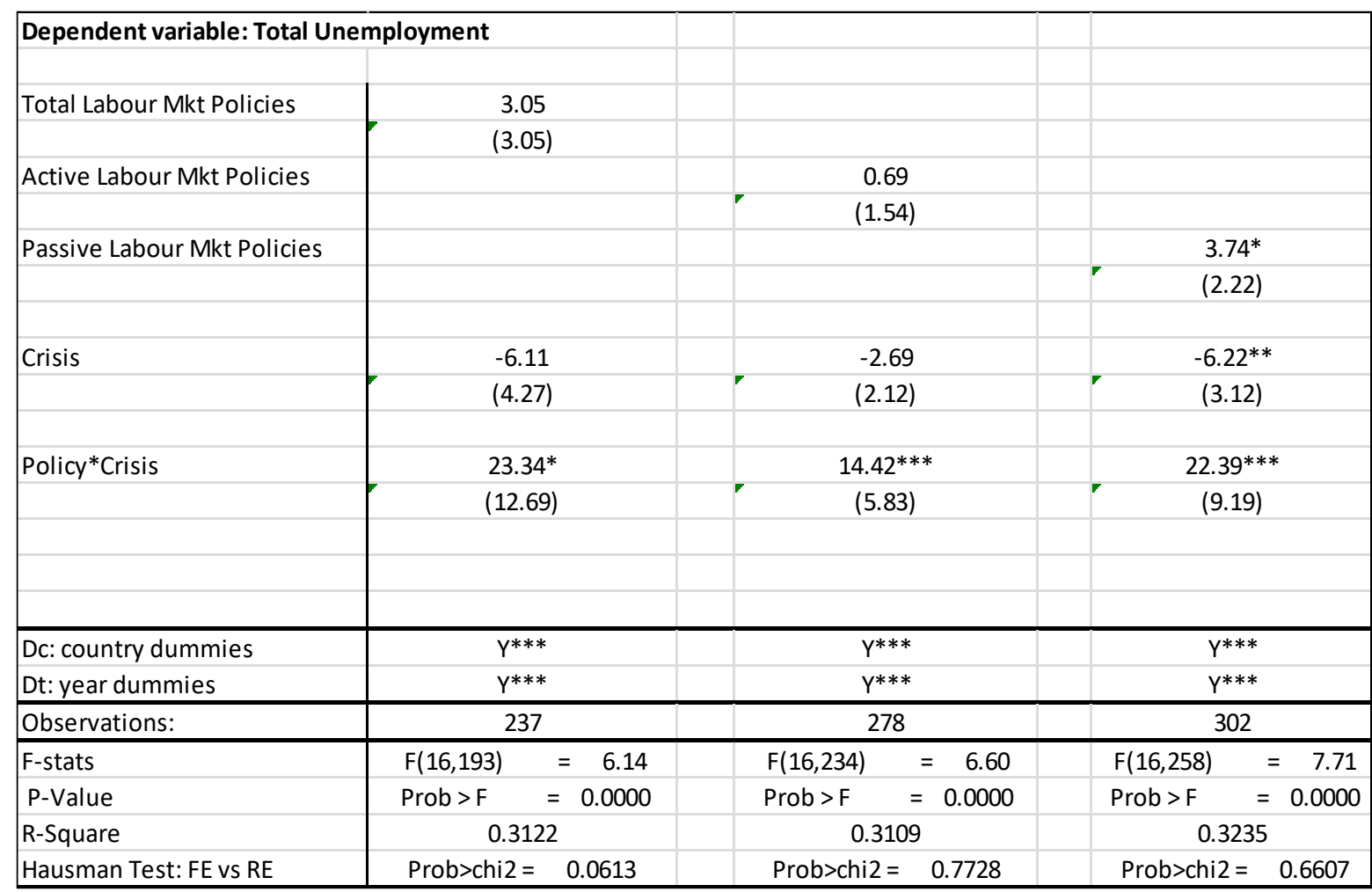

Notes: Standard errors in parentheses; * statistically significant at $10 \%$, ** statistically significant at $5 \%$ and $* * *$ statistically significant at $1 \%$.

Table 3 goes into much greater detail and decomposes the labour market policies into nine sub-components (for definitions of the variables see Table A1 in the Appendix). Rehabilitation and start-up expenses are now significant. Consequently, these results give us a much richer picture of the relation among the unemployment rate, policies, and financial crises. 
Table 3: Unemployment rate, Disaggregate Policies and Crisis

\begin{tabular}{|c|c|c|c|c|c|c|c|c|}
\hline \multicolumn{9}{|c|}{ Dependent variable: Total Unemployment } \\
\hline \multirow[t]{2}{*}{ Training } & -0.41 & & & & & & & \\
\hline & $(0.39)$ & & & & & & & \\
\hline & & & & & & & & \\
\hline \multirow[t]{2}{*}{ Job Rotation } & & 0.6 & & & & & & \\
\hline & & $(0.6)$ & & & & & & \\
\hline & & & & & & & & \\
\hline \multirow[t]{2}{*}{ Employment Incentives } & & & 0.63 & & & & & \\
\hline & & & $(0.52)$ & & & & & \\
\hline & & & & & & & & \\
\hline \multirow[t]{2}{*}{ Rehabilitation } & & & & $2.48^{* * *}$ & & & & \\
\hline & & & & $(0.78)$ & & & & \\
\hline & & & & & & & & \\
\hline \multirow[t]{2}{*}{ Job Creation } & & & & & 0.88 & & & \\
\hline & & & & & $(0.71)$ & & & \\
\hline & & & & & & & & \\
\hline \multirow[t]{2}{*}{ Start-up Incentives } & & & & & & $-0.43^{* * *}$ & & \\
\hline & & & & & & $(0.15)$ & & \\
\hline & & & & & & & & \\
\hline \multirow[t]{2}{*}{ Early Retirement } & & & & & & & -0.68 & \\
\hline & & & & & & & $(0.75)$ & \\
\hline & & & & & & & & \\
\hline \multirow[t]{2}{*}{$\begin{array}{l}\text { Out of work and } \\
\text { maintenance }\end{array}$} & & & & & & & & 3.52 \\
\hline & & & & & & & & $(2.18)$ \\
\hline & & & & & & & & \\
\hline \multirow[t]{2}{*}{ Crisis } & 1.78 & $10.04^{* *}$ & 0.17 & $5.13^{* * *}$ & 0.57 & 1.51 & -2.12 & $-5.4^{*}$ \\
\hline & $(2.21)$ & $(4.61)$ & $(1.53)$ & (2) & $(1.76)$ & $(1.44)$ & $(4.15)$ & $(2.87)$ \\
\hline \multirow[t]{2}{*}{ Policy*Crisis } & -0.66 & $-19.8^{*}$ & 4.8 & $-8.25^{* * *}$ & 2.74 & -2.24 & 13.48 & $20.57^{* *}$ \\
\hline & (3.33) & $(10.67)$ & (3.16) & (3.4) & $(4.65)$ & $(1.5)$ & $(10.11)$ & $(8.56)$ \\
\hline & & & & & & & & \\
\hline & & & & & & & & \\
\hline Dc: country dummies & $\gamma^{* * *}$ & $\gamma^{* * *}$ & $\gamma^{* * *}$ & $\gamma^{* * *}$ & $\gamma^{* * *}$ & $\gamma^{* * *}$ & $\gamma^{* * *}$ & $\gamma^{* * *}$ \\
\hline Dt: year dummies & $\gamma^{* * *}$ & $\gamma^{* * *}$ & $\gamma^{* * *}$ & $\gamma^{* * *}$ & $Y^{* * *}$ & $\gamma^{* * *}$ & $Y^{* * *}$ & $\gamma^{* * *}$ \\
\hline Observations: & 280 & 102 & 275 & 207 & 246 & 189 & 166 & 304 \\
\hline F-stats & $F(16,236)=6.23$ & $F(16,74)=3.35$ & $F(16,232)=6.01$ & $F(16,168)=5.80$ & $F(16,204)=4.03$ & $F(16,164)=4.63$ & $F(16,134)=2.30$ & $F(16,260)=7.59$ \\
\hline P-Value & Prob $>F=0.0000$ & Prob $>F=0.0002$ & Prob $>F=0.0000$ & Prob $>F=0.0000$ & Prob $>F=0.0000$ & Prob $>F=0.0000$ & Prob $>F=0.0051$ & Prob $>F=0.0000$ \\
\hline R-Square & 0.2969 & 0.4201 & 0.2931 & 0.356 & 0.2401 & 0.3113 & 0.2155 & 0.3184 \\
\hline Hausman Test: FE vs RE & Prob>chi2 $=0.0008$ & Probschi2 $=0.0000$ & Prob $>$ chi2 $=0.8318$ & Prob $>$ chi2 $=0.8242$ & Prob>chi2 $=0.3316$ & Prob>chi $2=0.0053$ & Probschi2 $=0.6920$ & Probschi2 $=0.6774$ \\
\hline
\end{tabular}

Notes: Standard errors in parentheses; * statistically significant at $10 \%$, ** statistically significant at $5 \%$ and $* * *$ statistically significant at $1 \%$.

In Tables 4 and 5 we consider Youth Unemployment as the dependent variable, and we investigate the same relationships (see Equation 2). The results are qualitatively unchanged, but now the country-specific crisis effect is much more important. 
Table 4: Youth Unemployment rate, Aggregate Policies and Crisis

\begin{tabular}{|c|c|c|c|}
\hline \multicolumn{4}{|c|}{ Dependent variable: Youth Unemployment } \\
\hline \multirow[t]{2}{*}{ Total Labour Mkt Policies } & 2.55 & & \\
\hline & $(6.12)$ & & \\
\hline \multirow[t]{2}{*}{ Active Labour Mkt Policies } & & 3.01 & \\
\hline & & (3.08) & \\
\hline \multirow[t]{2}{*}{ Passive Labour Mkt Policies } & & & 1.95 \\
\hline & & & $(4.56)$ \\
\hline \multirow[t]{2}{*}{ Crisis } & -10.77 & -2.47 & $-10.4^{*}$ \\
\hline & $(8.56)$ & $(4.25)$ & $(6.4)$ \\
\hline \multirow[t]{2}{*}{ Policy*Crisis } & 47.78* & $23.34 * *$ & $43.94 * *$ \\
\hline & $(25.43)$ & $(11.72)$ & $(18.84)$ \\
\hline Dc: country dummies & $\mathrm{Y}^{* * *}$ & $\mathrm{Y}^{* * *}$ & $Y^{* * *}$ \\
\hline Dt: year dummies & $\mathrm{Y}^{* * *}$ & $\mathrm{Y}^{* * *}$ & $\mathrm{Y}^{* * *}$ \\
\hline Observations: & 237 & 278 & 302 \\
\hline F-stats & $F(16,193)=7.66$ & $F(16,234)$ & $F(16,258)$ \\
\hline P-Value & Prob $>F \quad=0.0000$ & $=0.0000$ & $=0.0000$ \\
\hline R-Square & 0.3884 & 0.363 & 0.357 \\
\hline Hausman Test: FE vs RE & Prob $>$ chi $2=0.0007$ & Prob $>$ chi $2=0.4979$ & Prob $>$ chi2 $=0.8317$ \\
\hline
\end{tabular}

Notes: Standard errors in parentheses; * statistically significant at $10 \%, * *$ statistically significant at $5 \%$ and $* * *$ statistically significant at $1 \%$. 
Table 5: Youth Unemployment rate, Disaggregate Policies and Crisis

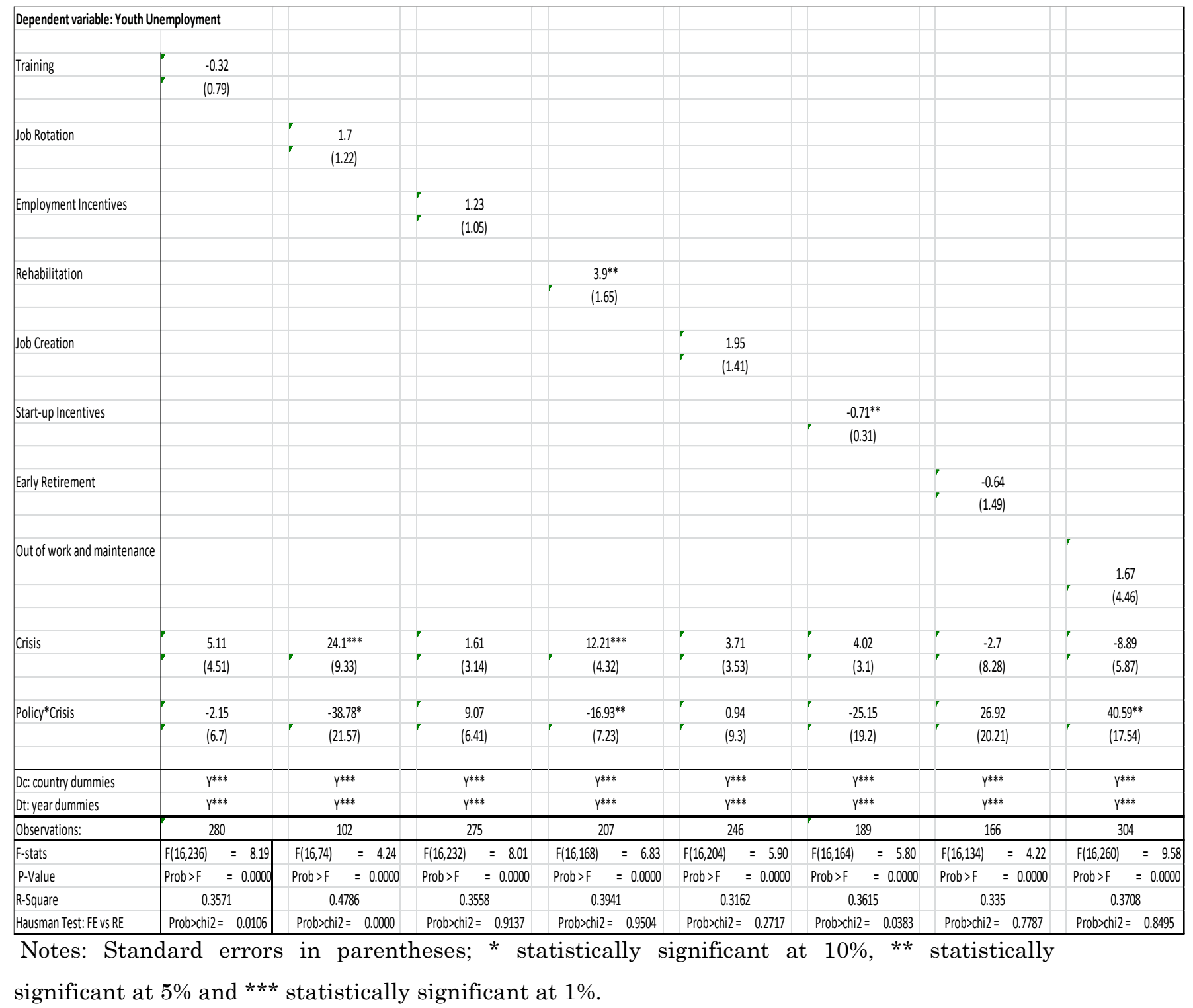

\subsection{Non-Monotonous Effects: accounting for Interactions}

In order to investigate the joint effect on unemployment of the crisis and policy variables, we used an interaction effect in each and every regression. This joint impact turned out to be non-monotonous. In other words, the impact of the crisis on unemployment was positive, non-significantly different from zero, or negative depending on the actual value of the policy variable. By the same token, the impact of the policy variable of unemployment was positive, non-significantly different from zero, or negative depending on the crisis's values. 
More in detail, the joint effect of policies and crisis on unemployment was calculated in two steps. First, we retrieved the estimated thresholds for policies and crisis. Thus, we found the value of crisis (policy) such that the policy (crisis) variable had zero impact on unemployment. Second, we evaluated the joint impact of policies and crisis from below and above the thresholds and thus assessed their non-monotonous effects. The steps taken in order to calculate the non-monotonous effect of Policy for the given Crisis Threshold were the following: 1) Finding the Crisis Threshold:

As the total effect of Policy on Unemployment Rate is equal to: $\hat{\beta}_{1}$ Policy $+\hat{\beta}_{3}($ Policy*Crisis $)$, the Crisis Threshold is such that: $\operatorname{Policy}\left(\hat{\beta}_{1}+\hat{\beta}_{3}\right.$ Crisis $)=0$ or $\left(\hat{\beta}_{1}+\hat{\beta}_{3}\right.$ Crisis $)=0$

Thus, the Crisis Threshold $=-\frac{\hat{\beta}_{1}}{\hat{\beta}_{3}}$

2) Assessing the non-monotonous effects of Policy for the calculated Crisis Threshold: this was simply done by evaluating whether the variable Policy increased (decreased) the unemployment rate, for crisis values above (below) the Crisis Threshold.

Likewise, the Policy Threshold was written as ${ }^{-\frac{\hat{\beta}_{2}}{\hat{\beta}_{3}}}$ and the non-monotonous effect of the crisis was assessed by evaluating whether the variable Crisis increased (decreased) the unemployment rate, for policy values above (below) the Policy Threshold. The formal construction of these thresholds is shown in Tables 6 and 7. Moreover, we provide a statistical interpretation in the following section 5.2 by looking at Graphs 1 to 9 .

Table 6: Non-monotonous effects, total unemployment 


\begin{tabular}{|c|c|c|c|c|c|c|c|c|c|}
\hline \multirow[t]{2}{*}{ Dependent variable: untot } & \multicolumn{3}{|c|}{ Statistical Significance } & $\begin{array}{c}\text { Crisis } \\
\text { Threshold } \\
\end{array}$ & \multicolumn{2}{|c|}{ Effect of Policy on unemployment rate } & \multirow{2}{*}{\begin{tabular}{|l|} 
Policy \\
Threshold
\end{tabular}} & \multicolumn{2}{|c|}{ Effect of Crisis on unemployment rate } \\
\hline & Policy & Crisis & Interaction & & Crisis>Threshold & Crisis $<$ Threshold & & Policy>Threshold & Policy<Threshold \\
\hline ratio_totlmp_on_gdppc & N.S. & N.S. & $\mathrm{S}^{*}$ & -0.130676949 & $\mathrm{u}$ increases & u decreases & 0.2617823 & $\mathrm{u}$ increases & u decreases \\
\hline ratio_almp_on_gdppc & N.S. & N.S. & $\mathrm{S}^{* * *}$ & -0.047595378 & $\mathrm{u}$ increases & u decreases & 0.1867811 & $\mathrm{u}$ increases & u decreases \\
\hline ratio_plmp_on_gdppc & s* & $\mathrm{S}^{* *}$ & $\mathrm{~S}^{* * *}$ & -0.167115053 & $\mathrm{u}$ increases & u decreases & 0.2775178 & $\mathrm{u}$ increases & $\mathrm{u}$ decreases \\
\hline ratio_train2_on_gdppc & N.S. & N.S. & N.S. & -0.629662182 & $\mathrm{u}$ decreases & $\mathrm{u}$ increases & 2.7124006 & $\mathrm{u}$ decreases & $\mathrm{u}$ increases \\
\hline ratio_rot3_on_gdppc training & N.S. & $\mathrm{S}^{* *}$ & $\mathrm{~S}^{*}$ & 0.030103224 & u decreases & $\mathrm{u}$ increases & 0.5073436 & u decreases & $\mathrm{u}$ increases \\
\hline ratio_emplinc4_on_gdppc & N.S. & N.S. & N.S. & -0.13058368 & $\mathrm{u}$ increases & $\mathrm{u}$ decreases & -0.034713 & $\mathrm{u}$ increases & u decreases \\
\hline ratio_rehab5_on_gdppc & $\mathrm{S}^{* * *}$ & $\mathrm{~S}^{* * *}$ & $\mathrm{~S}^{* * *}$ & 0.301064886 & u decreases & $\mathrm{u}$ increases & 0.623122 & $\mathrm{u}$ decreases & $\mathrm{u}$ increases \\
\hline ratio_jobcr6_on_gdppc & N.S. & N.S. & N.S. & -0.322139012 & $\mathrm{u}$ increases & $\mathrm{u}$ decreases & -0.208106 & u decreases & $\mathrm{u}$ increases \\
\hline ratio_stup7_on_gdppc & $\mathrm{s}^{* * *}$ & N.S. & N.S. & -0.191964286 & u decreases & $\mathrm{u}$ increases & 0.6741071 & u decreases & $\mathrm{u}$ increases \\
\hline ratio_outwork9_on_gdppc & N.S. & $\mathrm{S}^{*}$ & $\mathrm{~S}^{* *}$ & -0.171064037 & $\mathrm{u}$ increases & u decreases & 0.2624989 & $\mathrm{u}$ increases & u decreases \\
\hline
\end{tabular}

Table 7: Non-monotonous effects, Youth unemployment

\begin{tabular}{|c|c|c|c|c|c|c|c|c|c|}
\hline \multirow[t]{2}{*}{ Dependent variable: youthun } & \multicolumn{3}{|c|}{ Statistical Significance } & \multirow{2}{*}{$\begin{array}{l}\text { Crisis } \\
\text { Threshold }\end{array}$} & \multicolumn{2}{|c|}{ Effect of Policy on unemployment rate } & \multirow{2}{*}{\begin{tabular}{|l} 
Policy \\
Threshold
\end{tabular}} & \multicolumn{2}{|c|}{ Effect of Crisis on unemployment rate } \\
\hline & & & & & & & & & \\
\hline & Policy & Crisis & Interaction & & Crisis>Threshold & Crisis $<$ Threshold & & Policy>Threshold & Policy<Threshold \\
\hline ratio_totlmp_on_gdppc & N.S. & N.S. & $\mathrm{S}^{*}$ & -0.053369611 & $\mathrm{u}$ increases & u decreases & 0.2254081 & $\mathrm{u}$ increases & u decreases \\
\hline ratio_almp_on_gdppc & N.S. & N.S. & $\mathrm{S}^{* *}$ & -0.128947111 & $\mathrm{u}$ increases & u decreases & 0.1057561 & $\mathrm{u}$ increases & u decreases \\
\hline ratio_plmp_on_gdppc & N.S. & $\mathrm{S}^{*}$ & $\mathrm{~S}^{* *}$ & -0.04444604 & $\mathrm{u}$ increases & u decreases & 0.2367152 & $\mathrm{u}$ increases & u decreases \\
\hline ratio_train2_on_gdppc & N.S. & N.S. & N.S. & -0.150830285 & u decreases & $\mathrm{u}$ increases & 2.3746861 & u decreases & $\mathrm{u}$ increases \\
\hline ratio_rot3_on_gdppc training & N.S. & $\mathrm{S}^{* * *}$ & $\mathrm{~S}^{*}$ & 0.043737785 & u decreases & $u$ increases & 0.6206122 & u decreases & $u$ increases \\
\hline ratio_emplinc4_on_gdppc & N.S. & N.S. & N.S. & -0.136178183 & u increases & u decreases & -0.177807 & u increases & u decreases \\
\hline ratio_rehab5_on_gdppc & $S^{* *}$ & $\mathrm{~S}^{* * *}$ & $\mathrm{~S}^{* *}$ & 0.230278922 & u decreases & u increases & 0.7214596 & u decreases & u increases \\
\hline ratio_jobcr6_on_gdppc & N.S. & N.S. & N.S. & -2.08071527 & u decreases & $\mathrm{u}$ increases & -3.955298 & u increases & u decreases \\
\hline ratio_stup7_on_gdppc & $S^{* *}$ & N.S. & N.S. & -0.028230616 & u decreases & $\mathrm{u}$ increases & 0.159841 & u decreases & $u$ increases \\
\hline eret8_on_gdppc & N.S. & N.S. & N.S. & 0.023854445 & $\mathrm{u}$ increases & u decreases & 0.1005967 & $\mathrm{u}$ increases & u decreases \\
\hline ratio_outwork9_on_gdppc & N.S. & N.S. & $\mathrm{S}^{* *}$ & -0.041304753 & u increases & u decreases & 0.2191773 & $\mathrm{u}$ increases & u decreases \\
\hline
\end{tabular}

\subsection{Non-Monotonous Effects: Confidence Intervals of the interaction effects ${ }^{17}$}

Following Brambor et al. 2006, we now turn to detailed description of the statistical relevance and the marginal effects of the interaction terms stemming from our analyses. In the following graphs 1 to 5 (each composed of two panels) we show the marginal effect of the policy on the unemployment rate ( $\partial \mathrm{U} / \partial \mathrm{policy})$ conditional on the crises, as well as the marginal effect of the crisis ( $\partial \mathrm{U} / \partial$ crisis)

\footnotetext{
${ }^{17}$ We thank an anonymous referee for suggesting the interpretation of the marginal effects of interaction terms and their relevant statistical significance.
} 
conditional on the policies. In the same way we explore the marginal effects on

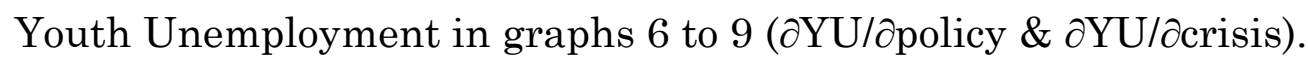

In other words, graphs 1 to 9 depict the joint effect of policies and crisis severity on the unemployment rate (or youth). The graphs can be read as follows. The blue line represents the linear marginal effect. The $95 \%$ confidence intervals are the lower bound (LB) red lines and the upper bound (UB) green ones. When both confidence intervals lie above (or below) the zero effect line, we can assess that there is a statically significant effect of the policy (or the crisis) on unemployment. If in the same graphs the confidence interval switches from above to below, then there is a statistically significant non-monotonous effect. We should also recall that both the policy and the crisis variables are constructed on a $(0,1)$ scale. Let us analyse them in order.

Graph 1: Tot unemployment rate: Total Passive Labour Market Policies (panel A) and the Crisis Joint Effect (panel B)

Panel A

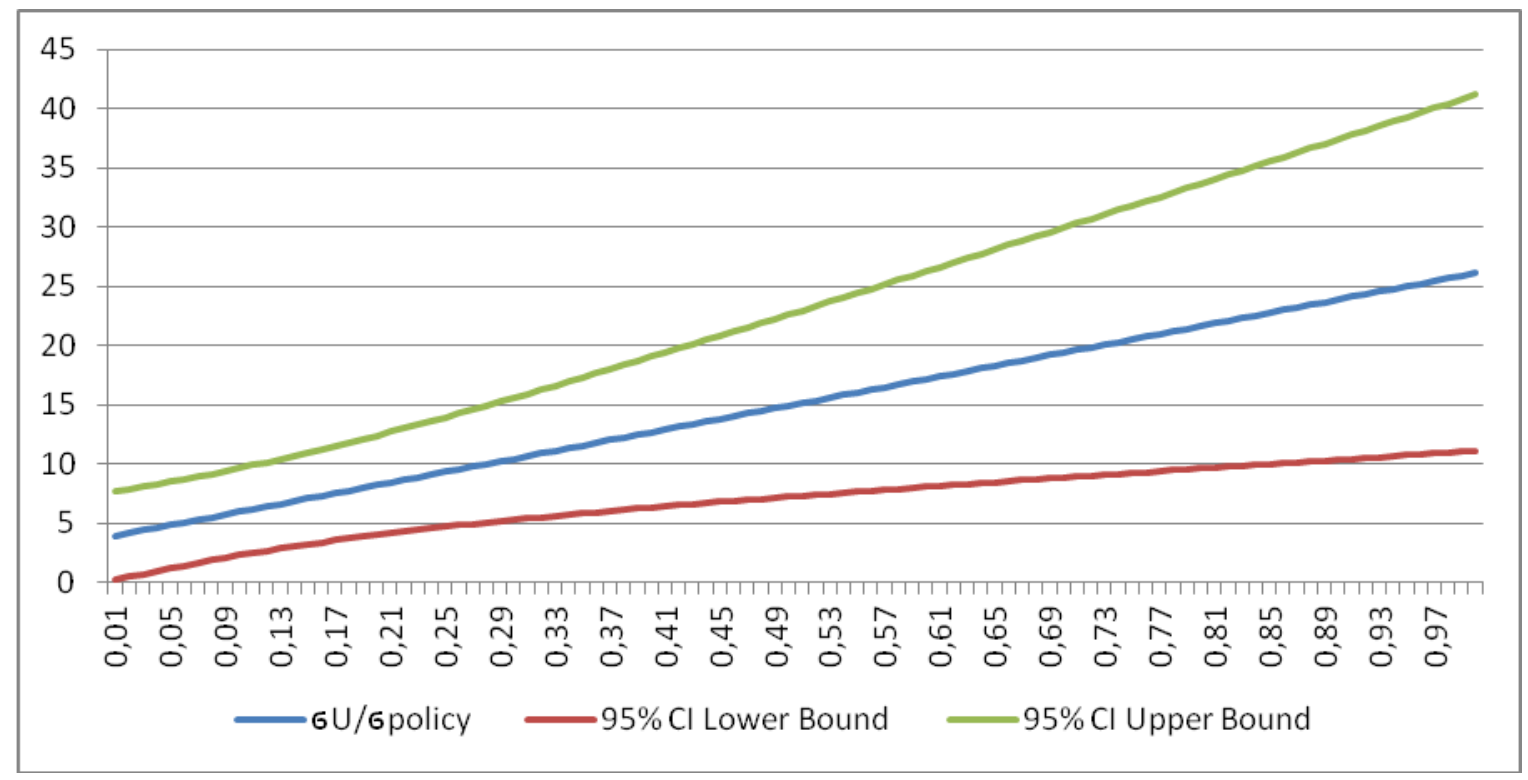

Panel B 


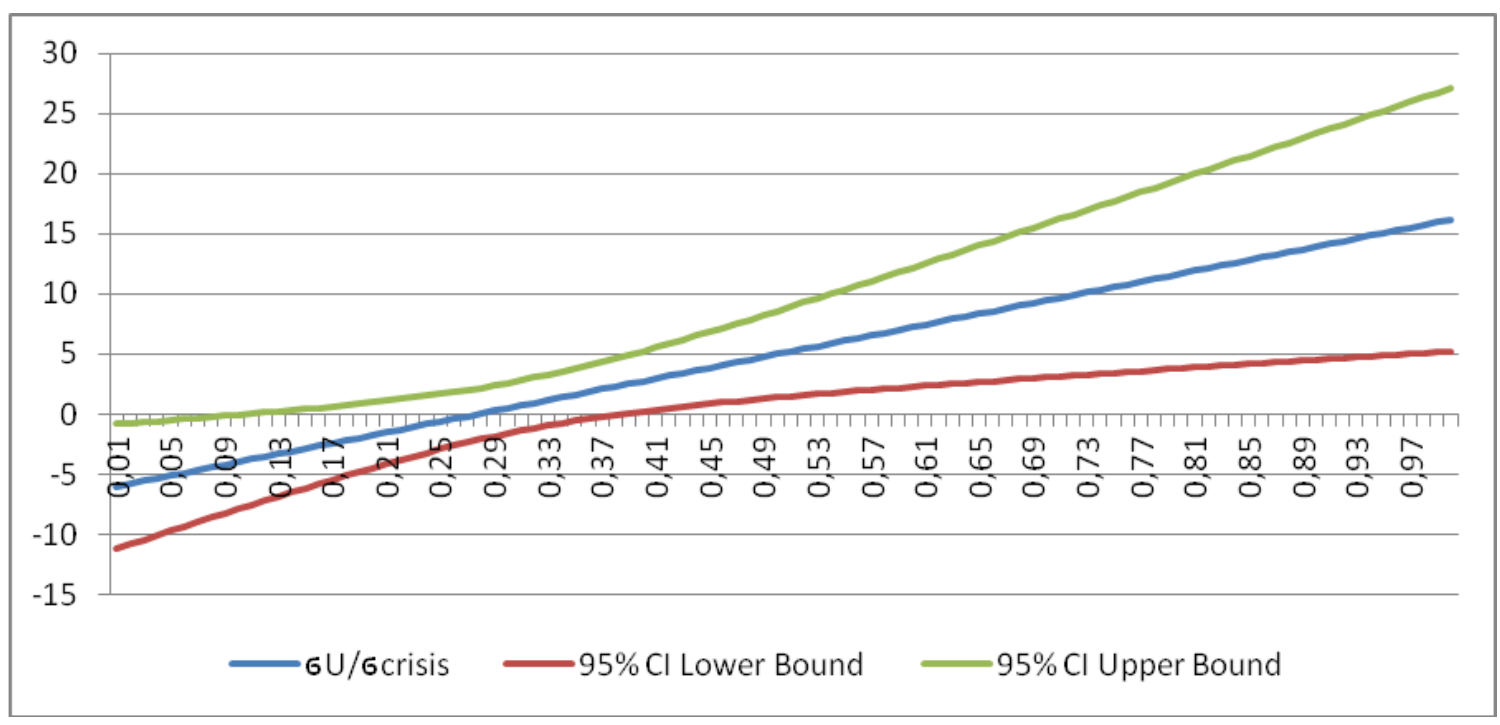

Both passive labour market policies and the crisis impact with a positive sign on unemployment, i.e. the more generous the policies and the more serious the crisis, the higher the unemployment rate. However, the crisis seems to work as a disciplining device whenever the level of the policy (opportunity cost of being employed) is below $9 \%$ of the average wage, i.e. below the point at which the upper bound of the CI hits the zero effect line. In other words, moderate levels of passive labour market policies may enhance a reduction of unemployment during a crisis, which is policy relevant.

Graph 2: Total unemployment Rate: Rotation Policies (panel A) and the Crisis (panel B) Joint Effect

Panel A

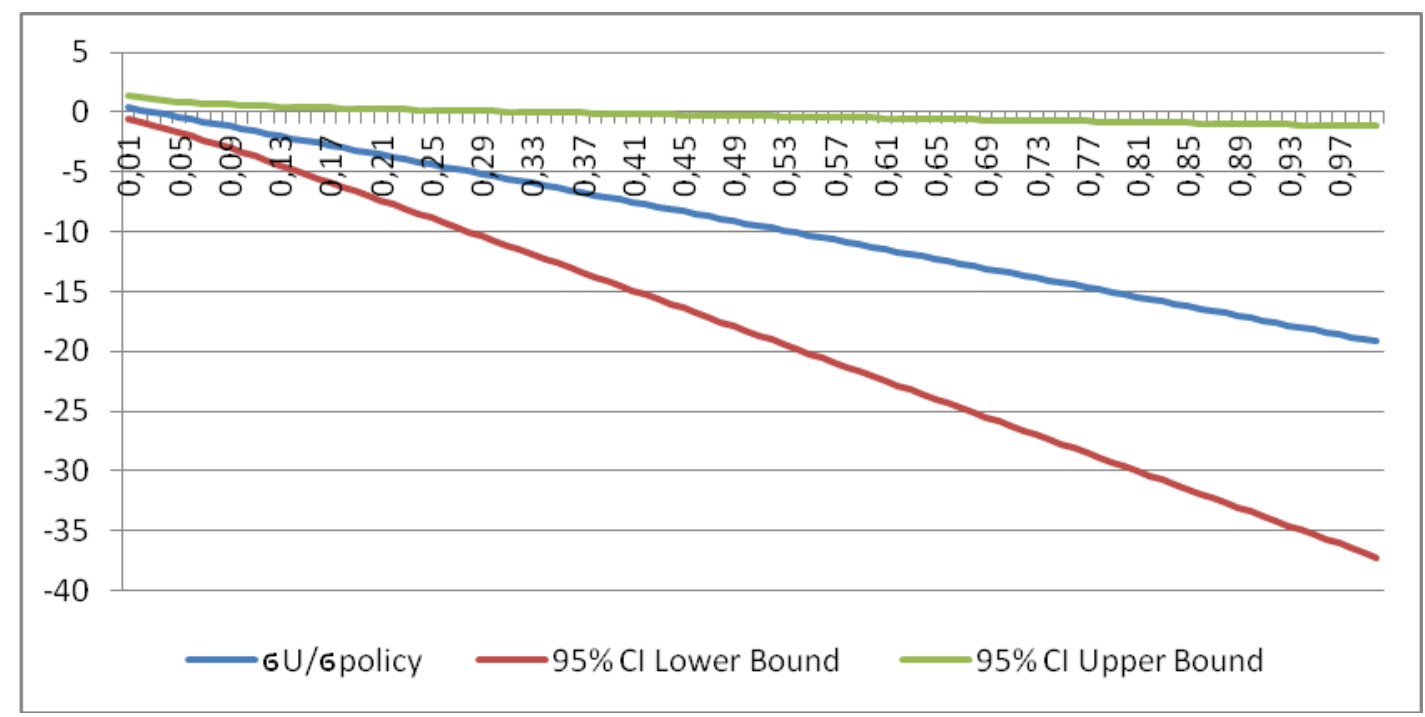

Panel B 


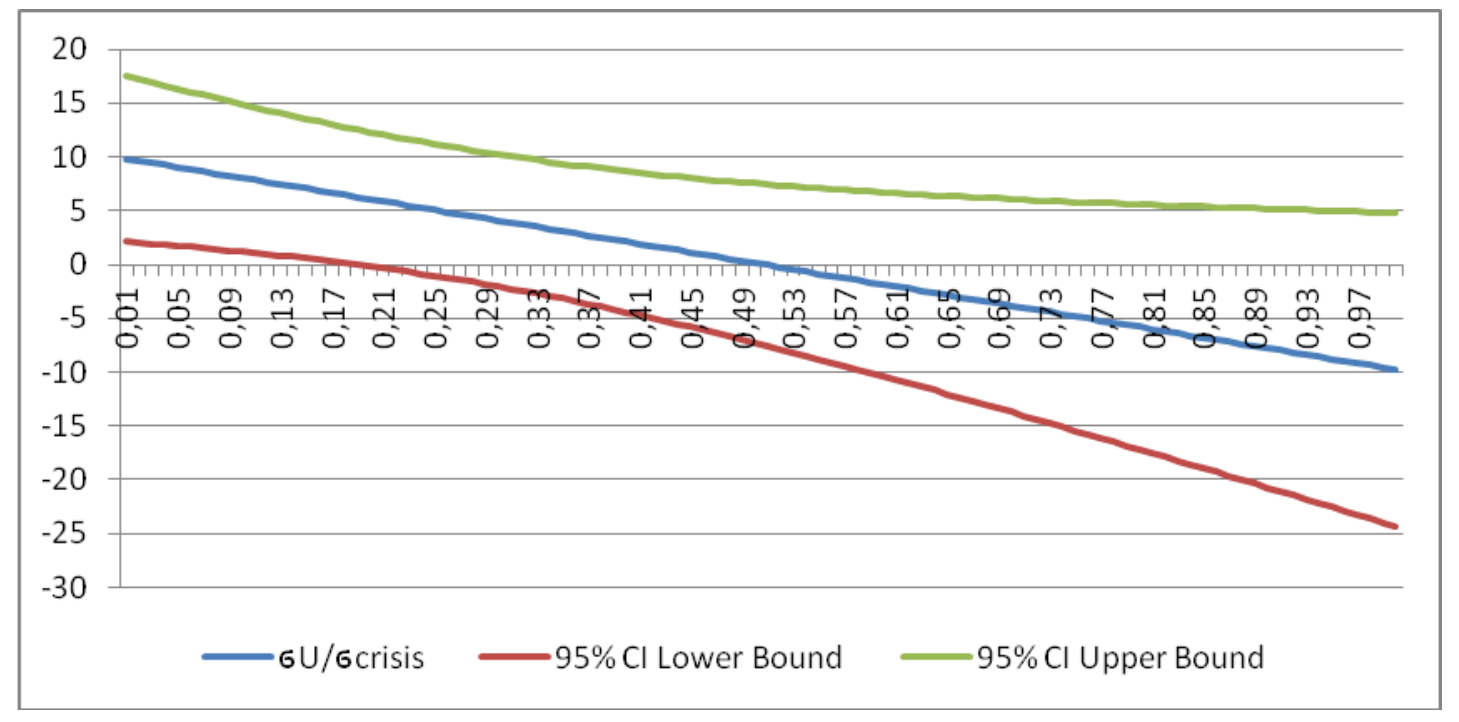

Rotation policies do not exert a marginal effect on unemployment. However, when the policies are below $20 \%$, the crisis has a positive impact on unemployment. We can interpret these results as a smoothing effect of rotation policies on the crisis's detrimental impact. The crisis is less unemployment conducive whenever the rotation-policies are relative higher.

Graph 3: Total unemployment Rate: Rehabilitation Policies (panel A) and the Crisis (panel B) Joint effect

Panel A

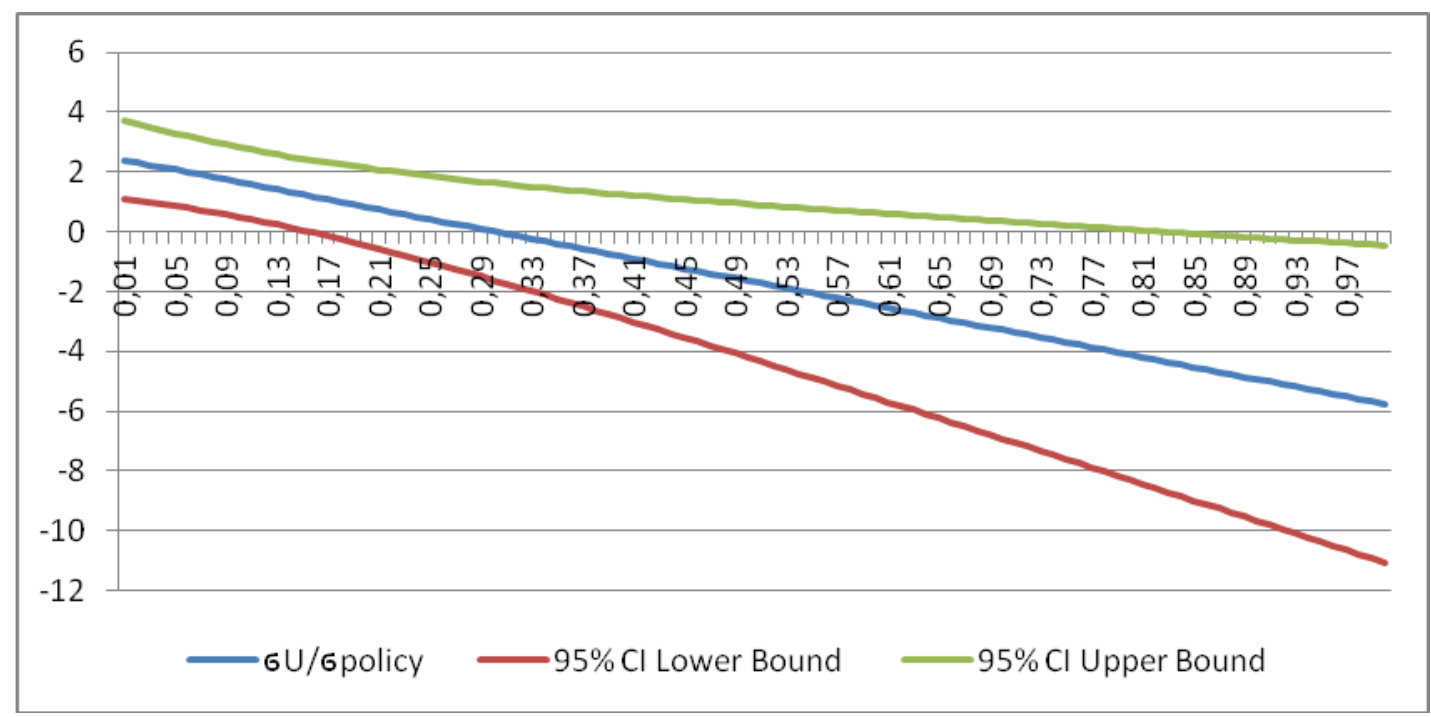

Panel B 


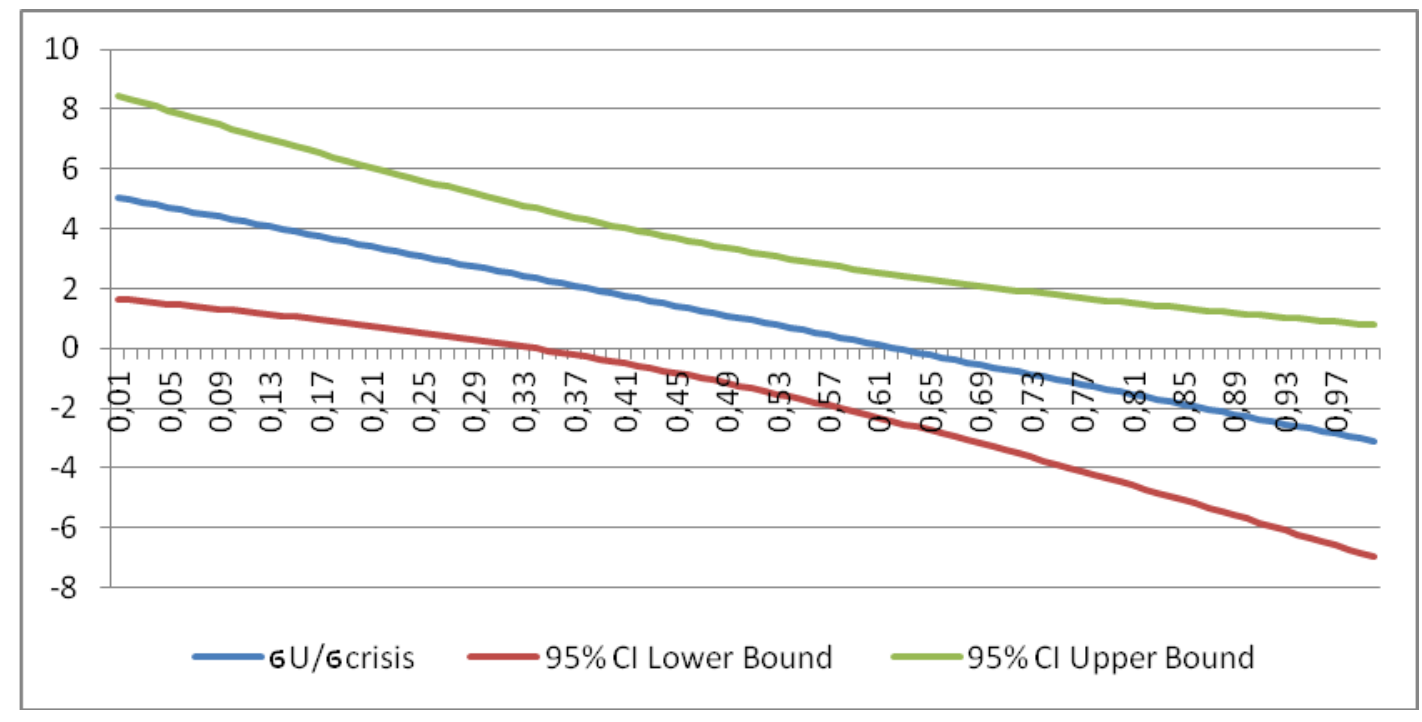

Rehabilitation policies register a genuine non-monotonous effect: when the crisis is less then $0.17 \%$ severe, they tend to increase unemployment; vice-versa when the crisis is extremely severe (more than 85\%) they tend to reduce unemployment. Similarly to the rotation policies, we can also assess that the crisis makes unemployment higher whenever the policies are below 33\%.

Graph 4: Total unemployment Rate: Start-up Policies (panel A) and the Crisis (panel B) Joint effect

Panel A

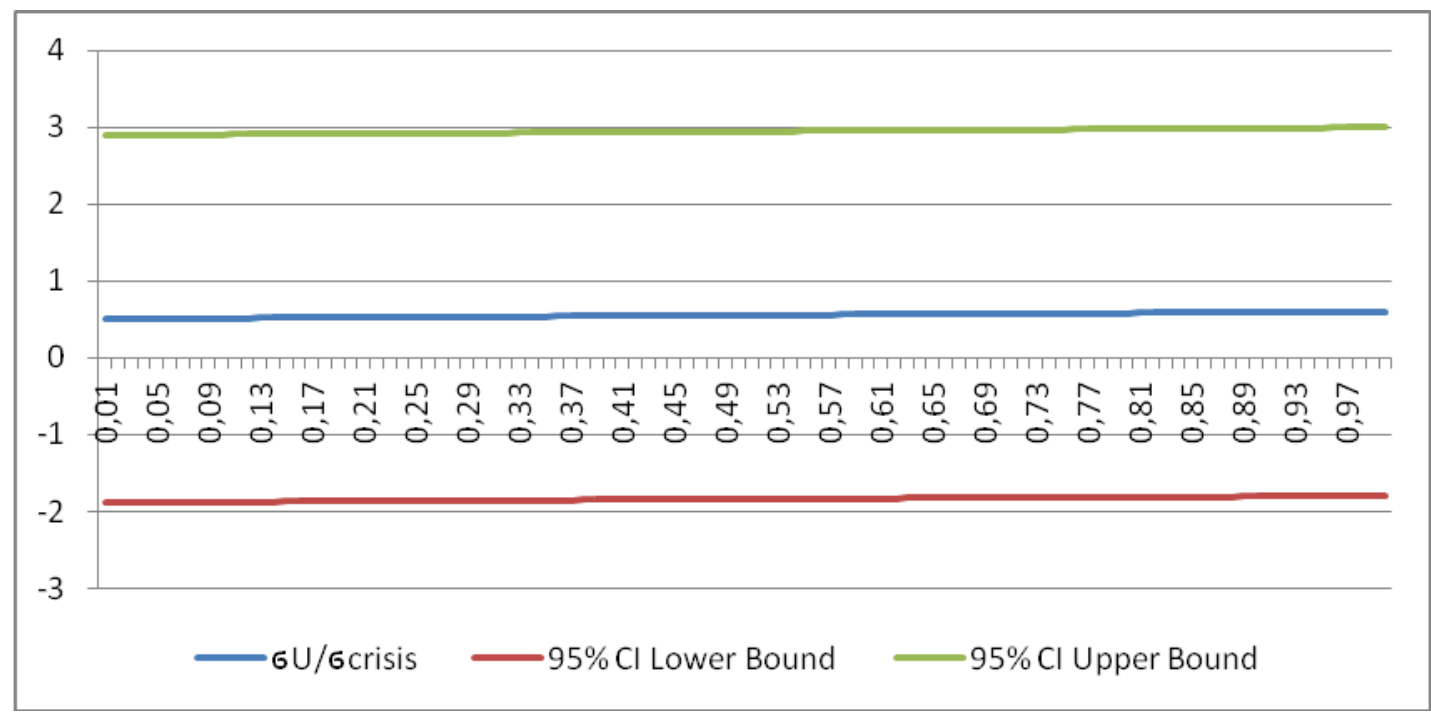

Panel B 


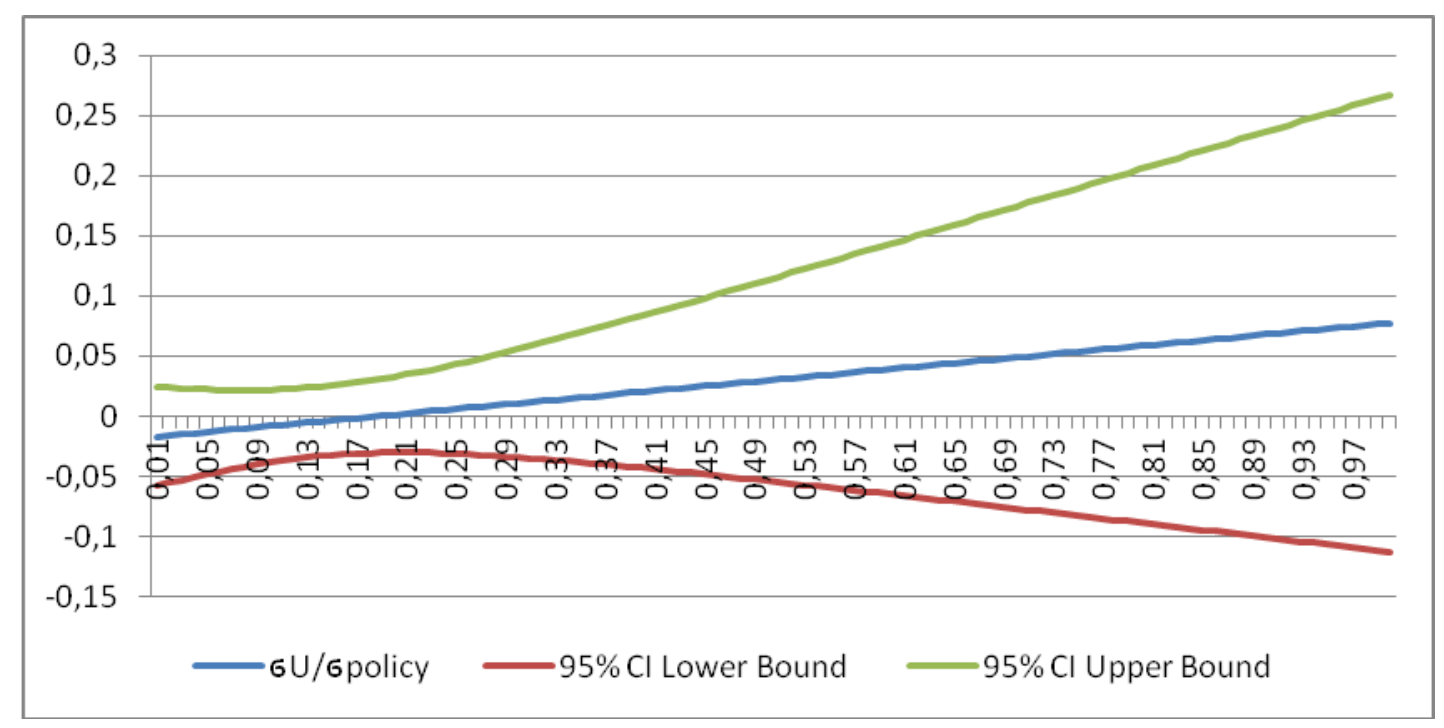

On a different note, start-up and crisis do not interact at all on unemployment, and this is highlighted by the very wide CI around the zero effect line.

Graph 5: Total unemployment Rate: Out of Work Policies (panel A) and the Crisis (panel B) Joint effect

Panel A

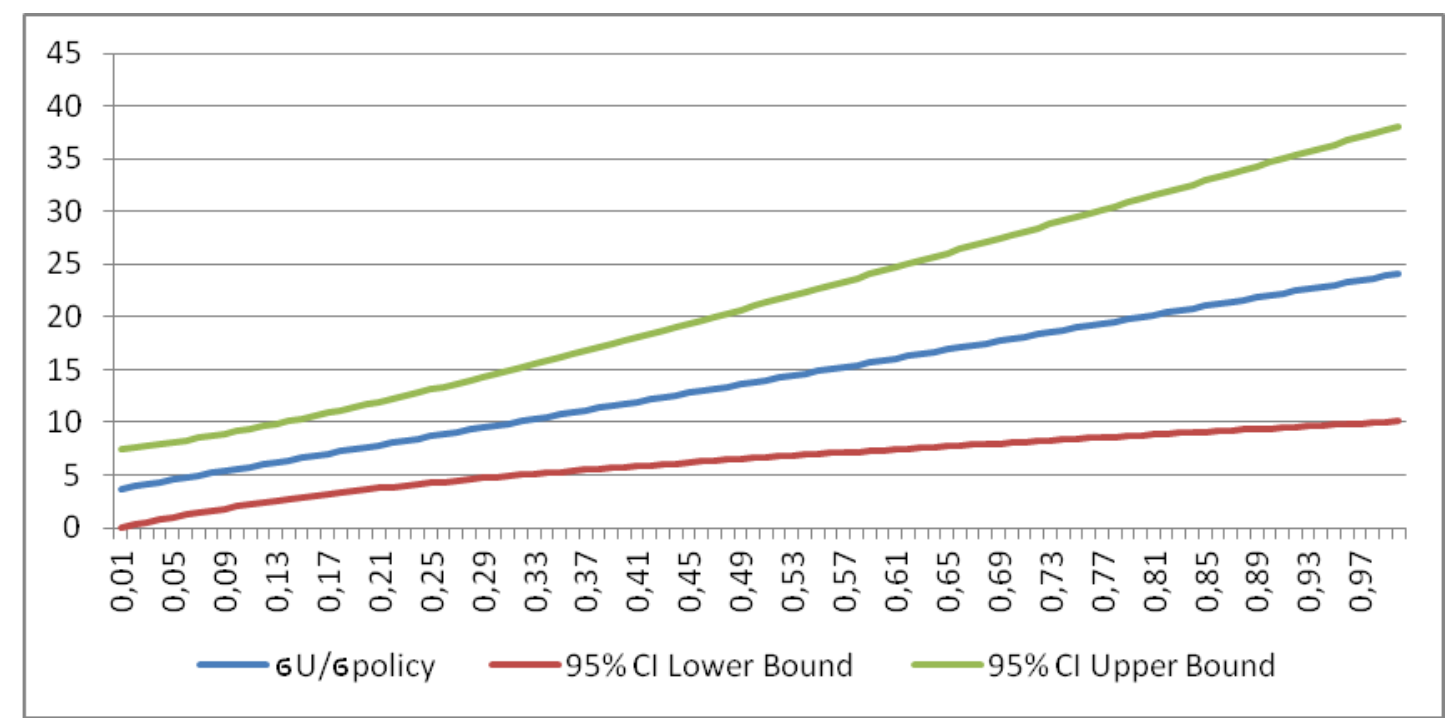

Panel B 


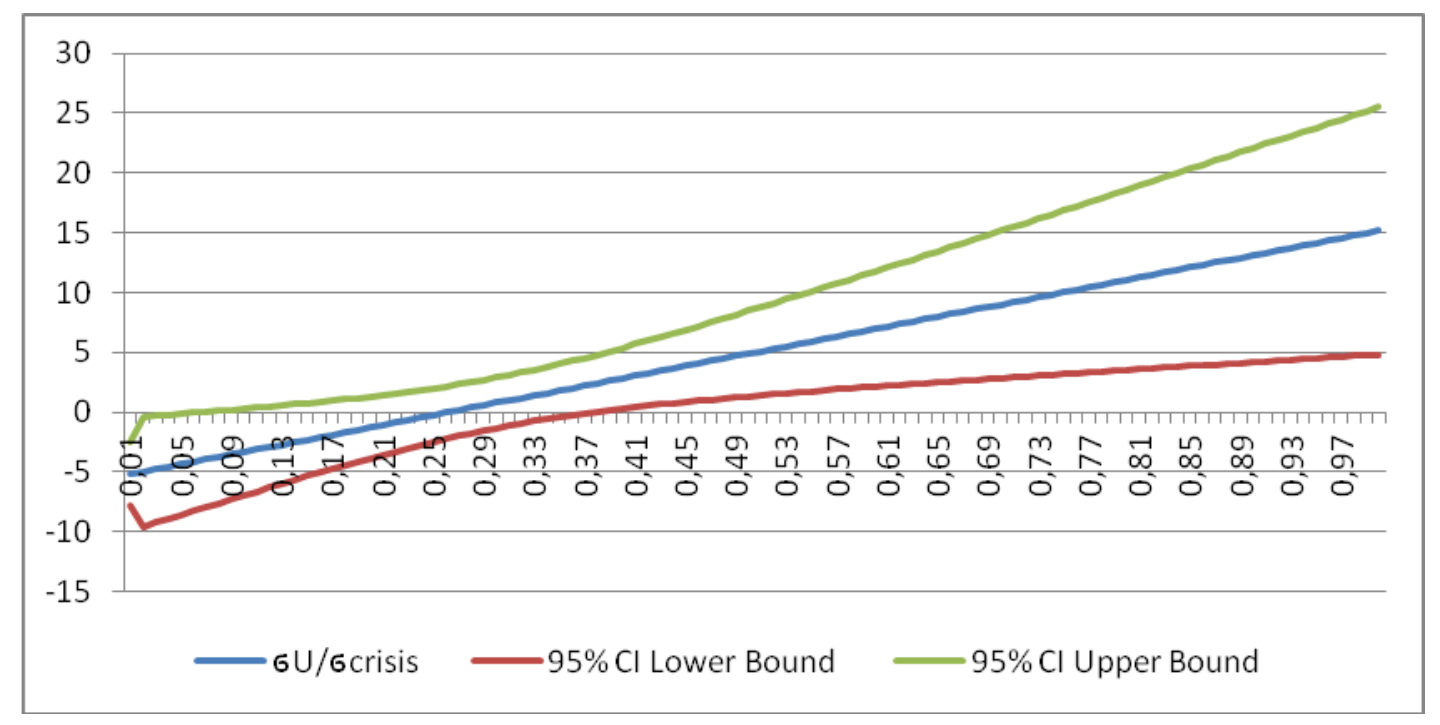

Out of labour force policies induce higher unemployment, and this effect is amplified by the crisis. By the same token, the crisis has an amplified effect when out of labour polices are excessively generous (above 40\%).

Graph 6: Youth unemployment rate: Total Passive Labour Market Policies (panel A) and the Crises (panel B) Joint Effect Panel A

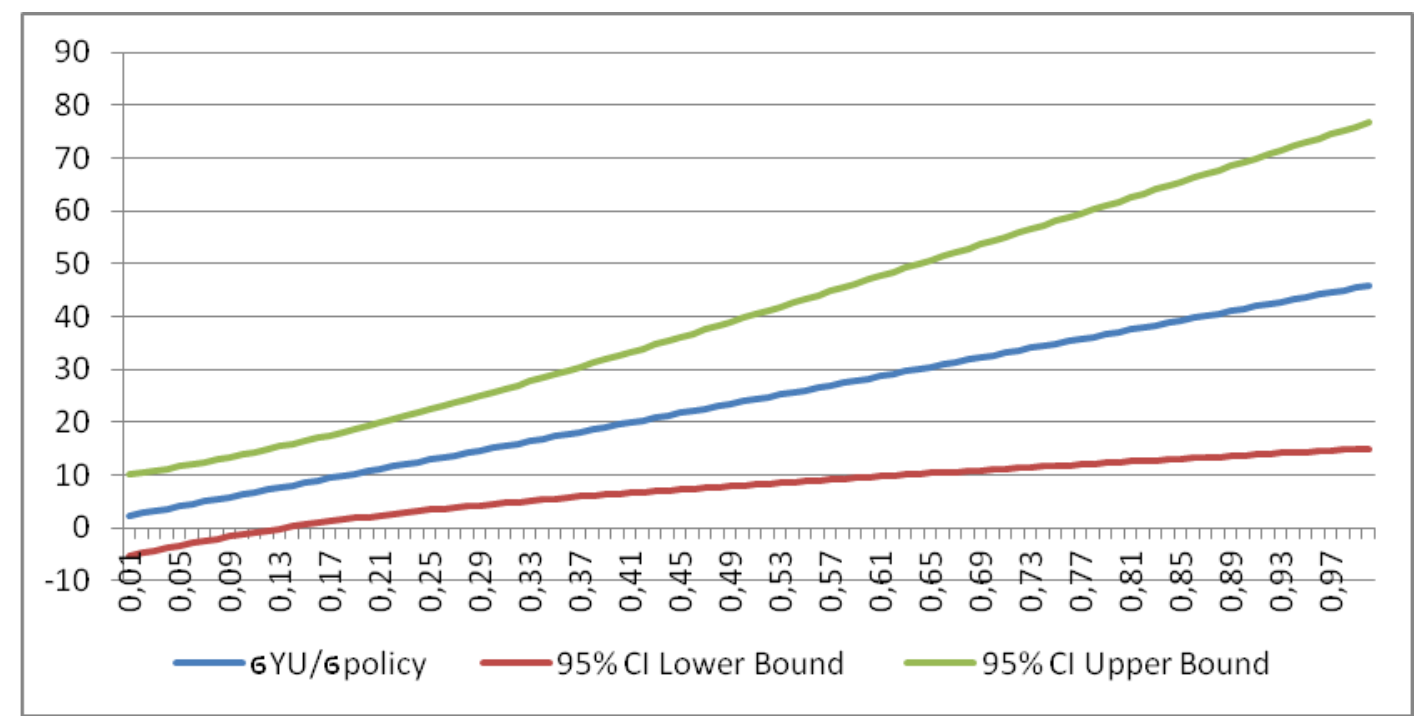

Panel B 


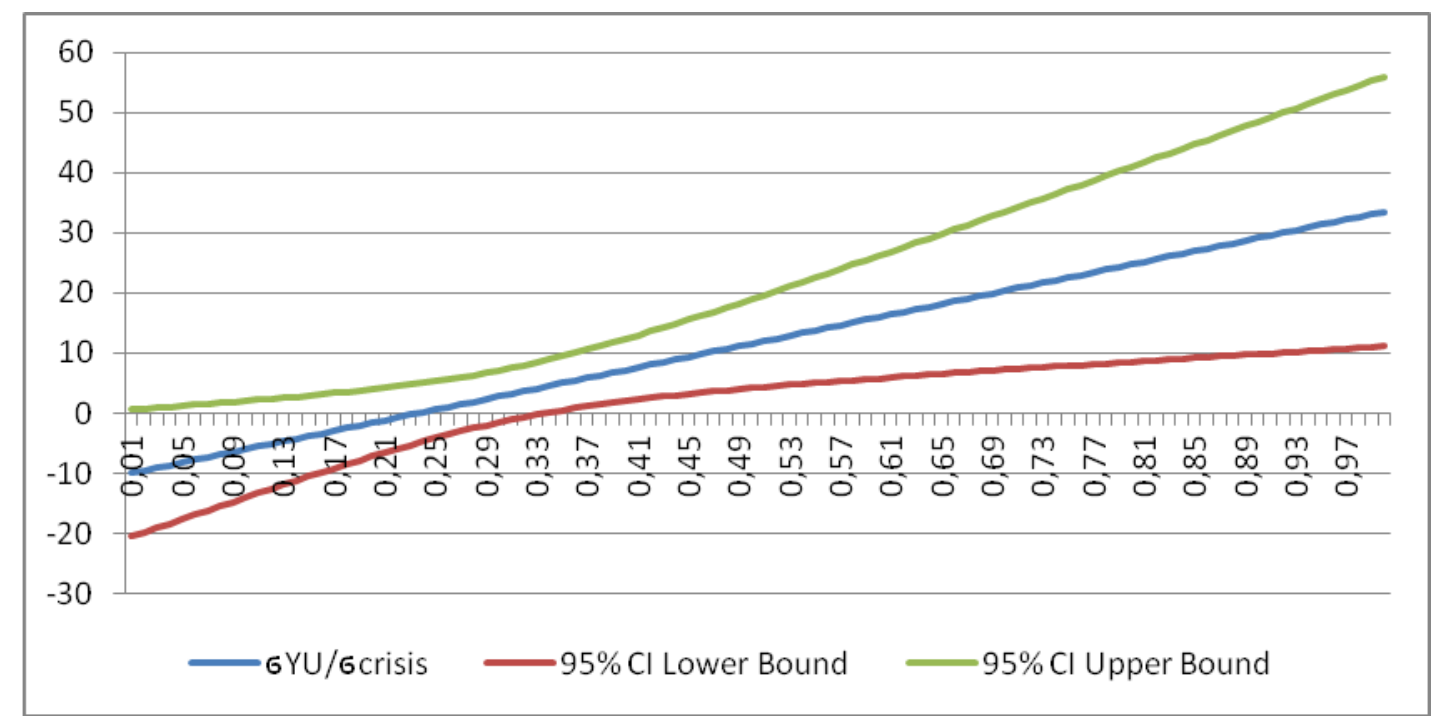

Total passive labour market policies are detrimental for the youth labour market when they are too generous, i.e. the worse the crisis (above 13\%) the higher the positive effect on unemployment. Conversely, the crisis is conducive to higher unemployment when the policies are more than $35 \%$.

Graph 7: Youth unemployment rate: Rotation Policies (panel A) and the Crisis (panel B) Joint Effect

Panel A

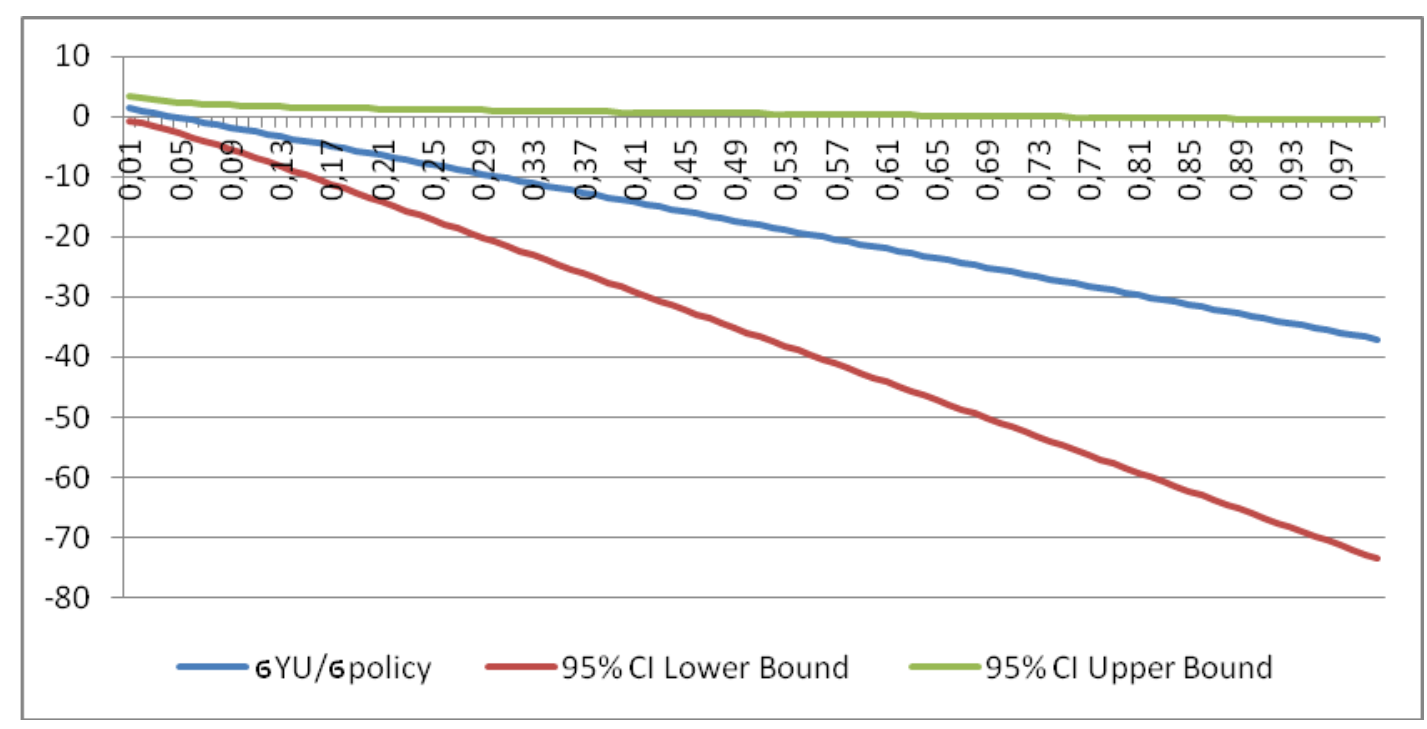

Panel B 


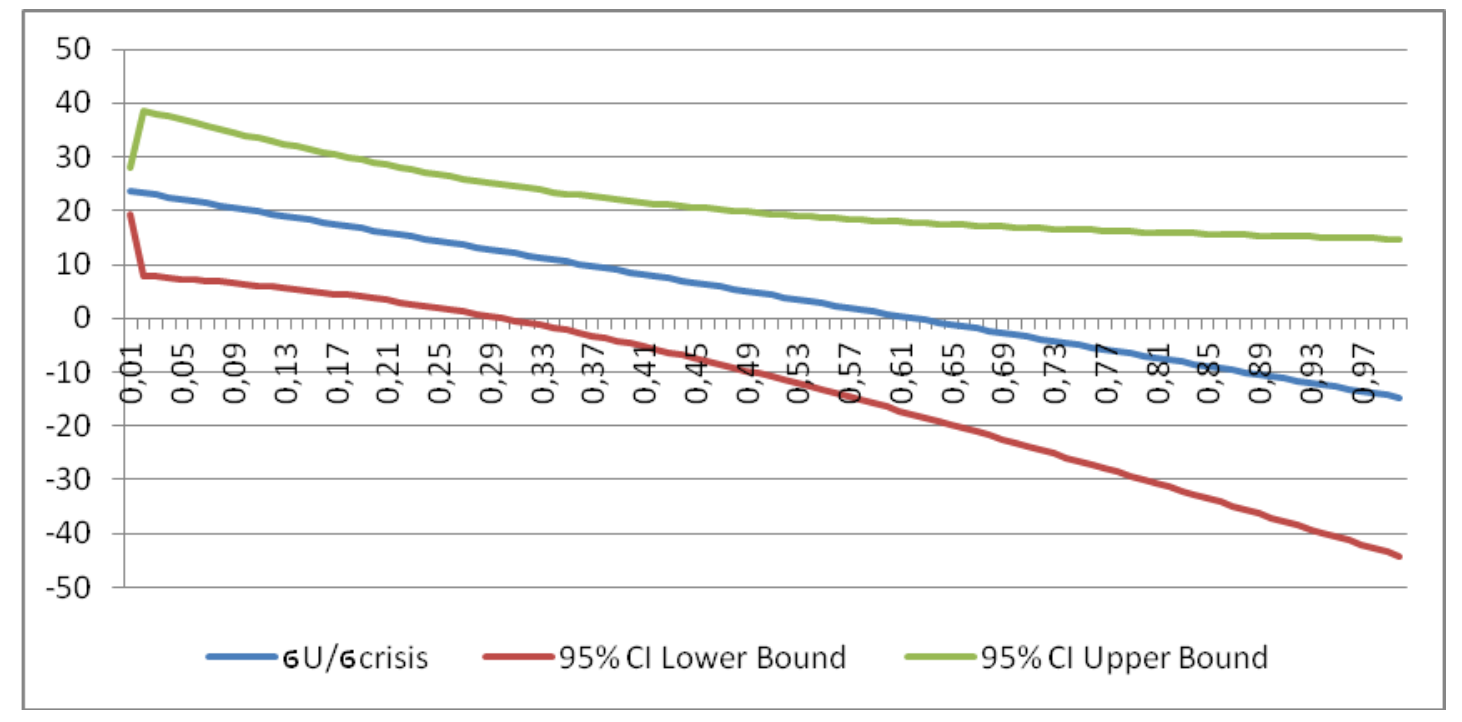

As regards rotation policies, we find a similar result to that for overall unemployment: no independent impact on youth unemployment but a mitigating effect with respect to the crisis's marginal effect. Below 29\%, the crisis hits the labour market, above $29 \%$ it does not.

Graph 8: Youth unemployment rate: Rehabilitation Policies (panel A) and the Crisis (panel B) Joint Effect

Panel A

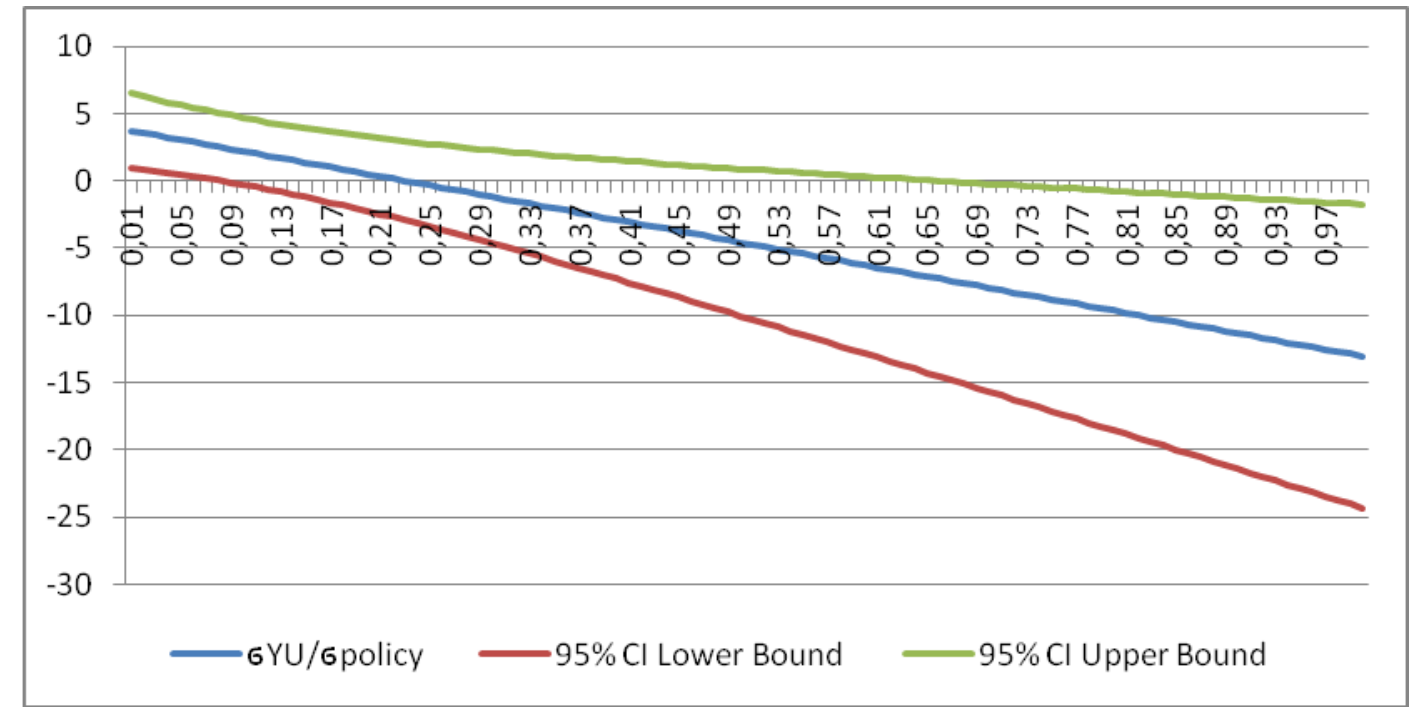

Panel B 


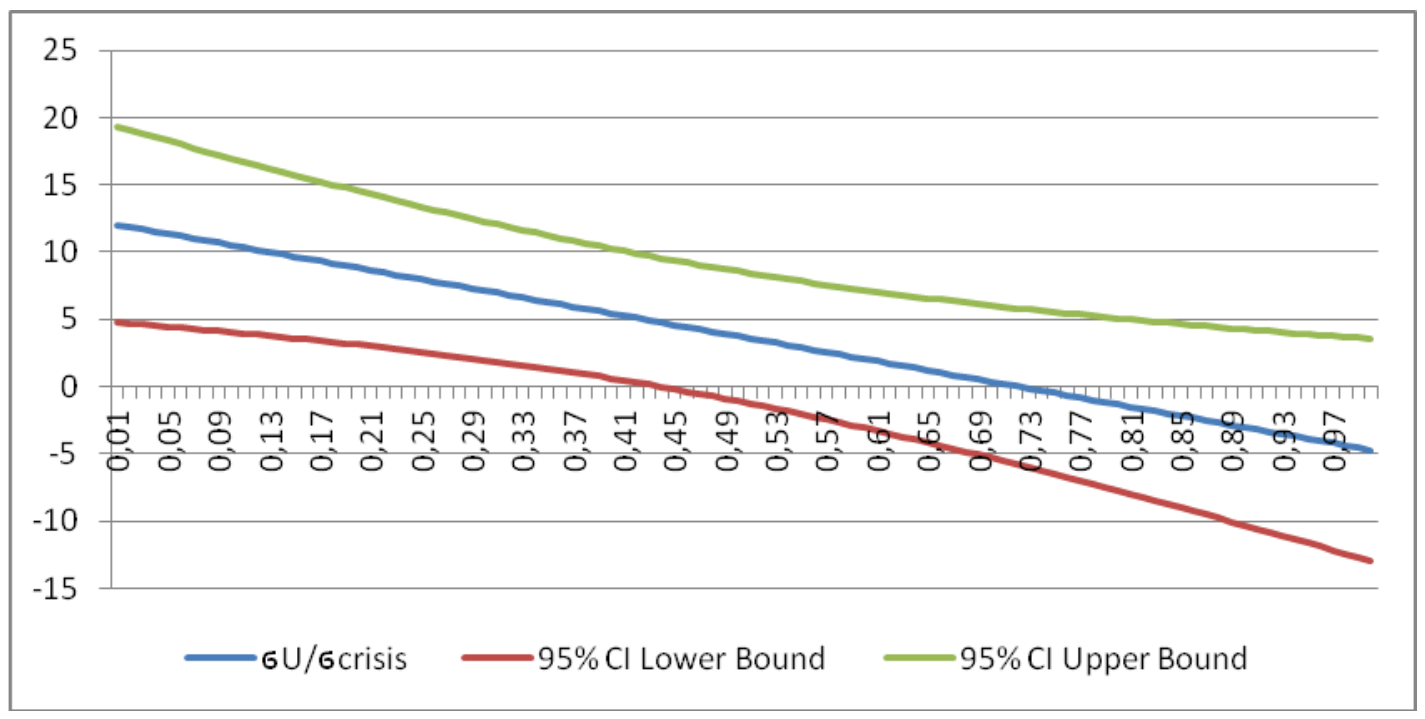

A genuine non-monotonous effect also appears for rehabilitation: for low levels of the crisis (in normal times) it seems to increase unemployment, but for a very severe crisis period it has the opposite effect. Again, the crisis hits unemployment positively for a value of the policies below $45 \%$ but then it fades away.

Graph 9: Youth unemployment rate: Start Up Policies (panel A) and the Crisis (Panel B) Joint Effect

Panel A

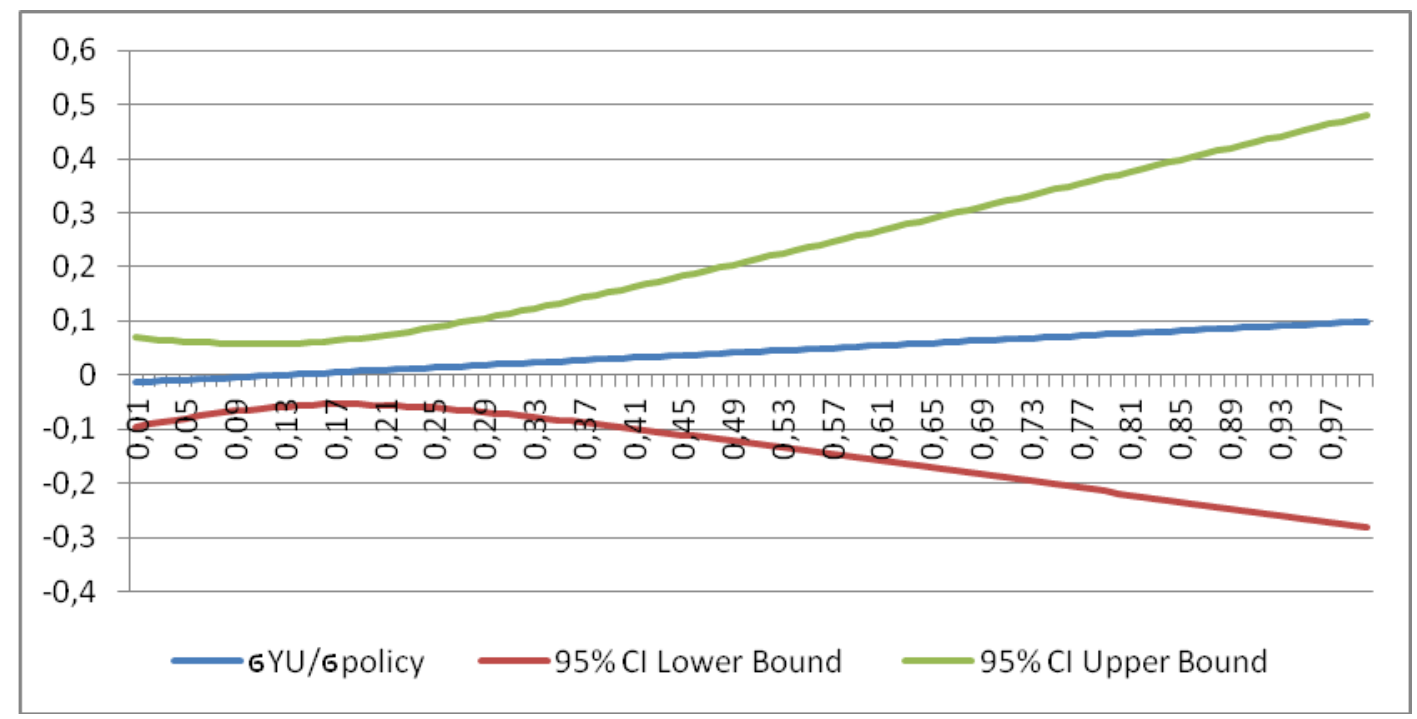

Panel B 


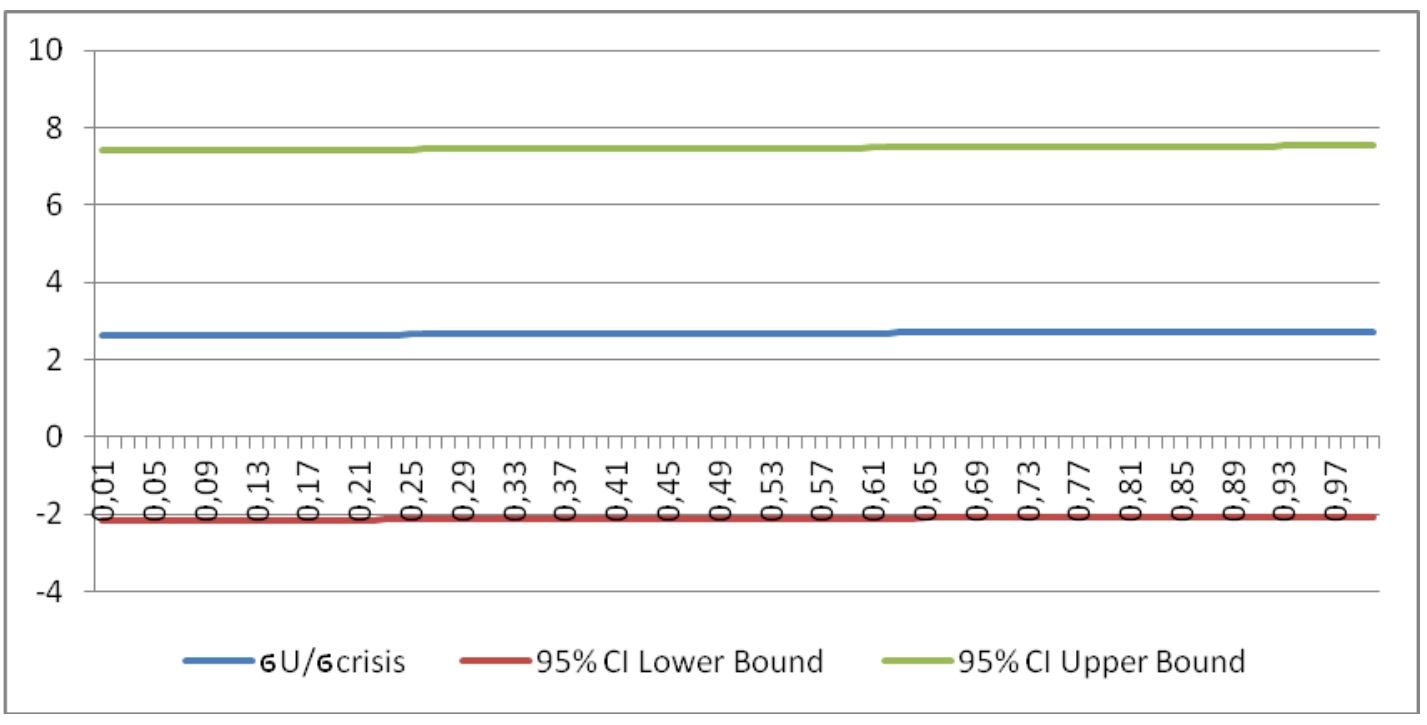

Finally, Start-up policies have no relevant and significant results on youth unemployment.

To sum up, we can comfortably conclude that all three testable hypotheses have been confirmed, but the impact of each and every policy is substantially different when interacted with the crisis - which in general exerts a positive impact on unemployment, as one would expect. We discuss these concluding results in the next section.

\section{Conclusions}

The aim of this paper has been to fill the gap in the literature concerning the complex joint impact of labour market policies and financial crises on labour market outcomes. In particular, we have addressed this research question by applying an innovative empirical approach to 30 European countries over the past two decades and considering the effects of the 2007-2008 financial crisis, which is associated with the "Great Recession". More in detail, we have measured labour market policies in terms of the opportunity cost of being employed instead of being a labour market policy beneficiary, and we have constructed a countryspecific and time-varying variable accounting for the idiosyncratic-severity effect of the last crisis. This pair of variables has enabled us to test the joint impact of labour market policies and economic crises on (total and youth) unemployment, exploiting the variability in both the cross-sectional and time dimension.

Operationally, we began by looking at an empirical specification able to disentangle the effect of the crisis on (total and youth) unemployment from the 
effect of labour market policies. This first step was instrumental in analysing the direct effect of these two separate components (crisis vs. policies) in the enlarged European context. In fact, we were interested in the combined effect of crisis and policies as our overall research question. As far as the interaction effect is concerned, our main findings are the following: passive labour market policies, ideally targeted on reducing the effects of crises by guaranteeing generous unemployment benefits, turn out to be detrimental in times of crisis, whereas they may be good policy instruments if they are not too generous; specific types of active labour market policies, such as rehabilitation and training incentives, are to be preferred in times of crisis because they may reduce unemployment more rapidly. Finally, young people should be targeted with special policies because they are particularly vulnerable to crises. Policy makers might therefore look at the complex joint effect of policies and crisis in order to design better general as well as specific, traditional as well as innovative, economic and labour policies.

Being aware of the specific nature of these results, we envisage further research ${ }^{18}$ on the channels through which economic crises and the labour market policies and institutions interplay in determining short and long run labour market performance. This is of key importance for any economist, decision maker or scholar working on the determinants of better and more jobs in the current European context characterised - especially in some countries - by a high risk of long stagnation without net job creation, i.e. with persistently high total and youth unemployment rates, after some years of more or less dramatic economic recession.

\footnotetext{
${ }^{18}$ For example by looking at the impact of the macroeconomic policies in times of crisis and/or by distinguishing Old vs. New EU member states.
} 


\section{References}

Acemoglu, Daron and Robert Shimer (2000). "Productivity Gains From Unemployment Insurance". European Economic Review 44, 1195-1224.

Algan, Y. and Pierre Cahuc (2009), "Civic Virtue and Labour Market Institutions", American Economic Journal: Macroeconomics, Vol.1(1), January

Auer, Peter (2010) 'Does flexicurity work in economic crises?' International Institute for Labour Studies ILO, Geneva Draft version, May 5/2010

Bassanini A. and Duval R. (2006), Employment Patterns in OECD Countries: Reassessing the Role of Policies and Institutions, OECD Economics Department working paper, 486.

Bernal-Verdugo E.L., Furceri D. and Guillaume D. (2012), "Labor Market Flexibility and Unemployment: New Empirical Evidence of Static and Dynamic Effects", Comparative Economic Studies, 3.

Blanchard, O. and J. Wolfers (2000) 'The Role of Shocks and Institutions in the Rise of European Unemployment: The Aggregate Evidence'. The Economic Journal, Vol. 110, C1-C33.

Blanchard, O. and L. H Summers (1987) 'Hysteresis in Unemployment'. The European Economic Review, Vol 31, pp. 288-295.

Betcherman, G., Olivas, K. and Dar, A. (2004) 'Impacts of Active Labour Market Programmes: New Evidence from Evaluations with Particular Attention to Developing and Transition Countries'. World Bank - Social Protection Discussion Paper No. 0402.

Boeri, T. (2002) 'Let Social Policy Models Compete and Europe Will Win'. Paper presented at a Conference hosted by the Kennedy School of Government, Harvard University, 11-12 April 2002.

Boeri, Tito, J. I. Conde-Ruiz and Vincenzo Galasso (2012), "The Political Economy of Flexicurity", Journal of the European Economic Association, Vol 10(4) pp. 684-715. 
Boeri, T.; Garibaldi, P. and Moen, E.R. (2013). "Financial Shocks and Labor: Facts and Theories", IMF Economic Review, Vol. 61(4), p.631-663.

Brandt N., Burniaux J.M. and Duval R. (2005), Assessing the OECD Jobs Strategy: Past Developments and Reforms, OECD Economics Department working paper, 429.

Bruno, R. L. (2006) Optimal Speed of Transition with a Shrinking Labour Force and under Uncertainty, Economics of Transition, Vol. 14(1), 69-100

Bruno, R. L. and Riccardo Rovelli (2010), "Labour Market Policies and Outcomes in the Enlarged EU”, Journal of Common Market Studies, Vol. 48(3), pp. 661686.

Brada, J.C. and Marcello Signorelli (2012), "Comparing Labour Market Performance: Some Stylized Facts and Key Findings", Comparative Economic Studies, 2.

Caroleo F.E. and Pastore F. (2007), "The Youth Experience Gap: Explaining Differences Across EU Countries", Quaderni del Dipartimento di Economia, Finanza e Statistica, Università di Perugia, 41.

Carmeci L., Mauro L. (2003). Long Run Growth and Investment in Education: Does Unemployment Matter?, Journal of Macroeconomics, 25, 123-137.

Choudhry Misbah, Enrico Marelli and Marcello Signorelli (2012), "Youth Unemployment and the Impact of Financial Crises", International Journal of Manpower, 1.

Destefanis S. and Mastromatteo G. (2010), "Labour-market Performance in the

OECD: Some Recent Cross-country Evidence", International Journal of Manpower, 31, 7, 713-31.

Esping-Andersen, G. (1996) The Three Worlds of Welfare Capitalism, Polity Press.

Esping-Andersen, G. (1999) Social Foundations of Post-industrial Economies, Oxford University Press: Oxford.

Farmer, R.E.A., 1985, "Implicit Contracts with Asymmetric Information and Bankruptcy: The Effect of Interest Rate on Layoffs," Review of Economic Studies, Vol. LII, pp. 427-42.

Feldmann H. (2010), "Economic Freedom and Unemployment", chapter 5 in: Economic Freedom of the World, Annual Report. 
Fiori, G., Nicoletti, G., Scarpetta, S. and Schiantarelli, F. (2008) Employment Outcomes and the Interaction Between Product and Labour Market Deregulation: Are They Substitutes or Complements?, Paper presented at the IMF conference on the Causes and Consequences of Structural Reforms held on the 28-29 February 2008 at Washington D.C.

Furceri D. and Mourougane A. (2009), "The Effect of Financial Crises on Potential Output: New Empirical Evidence from OECD countries", OECD Economics Department Working Paper, 699, Paris.

Greenwald, Bruce C. and J.E. Stiglitz, 1987, "Imperfect Information, Credit Markets and Unemployment,” European Economic Review, Vol. 31, No. (1-2), pp. $444-56$.

Hart, Oliver D, 1983, “Optimal Labor Contracts under Asymmetric Information: An Introduction,” Review of Economic Studies, Vol. 50, No. (1), pp. 3-35.

Heckman, J. and Pagés, C. (2003) 'Law and Employment: Lessons from Latin America and the Caribbean'. NBER Working Paper No. 10129.

Holmstrom, B. and J. Tirole, 1997, "Financial Intermediation, Loanable Funds, and the Real Sector," Quarterly Journal of Economics, Vol. CXII, No. (3), pp. 1997.

ILO (2010). Global Employment Trends for Youth. Special Issue on the Impact of Global Economic Crisis on Youth. International Labour Organization, Geneva, August.

ILO (2012), Global Employment Trends for Youth 2012, Geneva.

IMF (2010), "Unemployment Dynamics During Recessions and Recoveries: Okun's Law and Beyond", Chapter 3 in World Economic Outlook: Rebalancing Growth, Washington.

Jørgensen, Henning (2010) "Danish flexicurity" in crisis - or just stress-tested by the crisis? Report to the Friedrich Ebert Foundation, October 2010

Lee J. (2000), “The Robustness of Okun's law: Evidence from OECD Countries”, Journal of Macroeconomics, 22(2): 331-56.

Laeven, Luc and Fabian Valencia (2008) "Systemic Banking Crises: A New Database "IMF Working Paper 08/224 
Laeven, Luc and Fabian Valencia (2010) "Resolution of Banking Crises: The Good, the Bad, and the Ugly" IMF Working Paper 10/146

Layard, Richard and Nickell, S. (1987), "The Labour Market", in R. Dornbusch and R. Layard eds., The Performance of the British Economy, Oxford, Claredon Press.

Lyhne Ibsen, Christian (2010) "Strained compromises? Flexicurity during crisis" FAOS, University of Copenhagen, Track 3: Employment policies - labour demand, demography and social partners, 2010

Mortensen, Dale and Christopher Pissarides, (2001) Unemployment Responses to "Skill-Biased" Shocks: The Role of Labor Market Policy, Economic Journal, 109 (242-265).

Nickell, S. (1997), 'Unemployment and Labour Market Rigidities: Europe versus North America'. The Journal of Economic Perspectives, Vol. 11, No. 3, pp. 5574.

Nickell, S., Nunziata, L. and Ochel, W. (2005), 'Unemployment in the OECD since the 1960s: What Do We Know?' The Economic Journal, Vol. 115, pp. 127.

Marelli E., M. Choudhry and M. Signorelli (2013), "Youth and Total Unemployment Rate: The Impact of Policies and Institutions”, Rivista Internazionale di Scienze Sociali, 1.

Marelli E., Patuelli R. and Signorelli M. (2012), "Regional Unemployment in the EU before and after the Global Crisis”, Post-Communist Economies, 2.

Monacelli, Tommaso, Quadrini, Vincenzo, and Antonella Trigari, 2011, "Financial Markets and Unemployment," NBER Working Papers 17389, National Bureau of Economic Research, Inc.

OECD (1994), OECD Jobs Study, Paris.

OECD (2005), Education at Glance, Paris.

OECD (2006), Employment Outlook, Paris.

O'Higgins N. (2011). The Impact of the Economic and Financial Crisis and the Policy Response on Youth Employment in the European Union, presented at the Eaces International Workshop, Perugia, November 10-11. 
O'Higgins N. (2012). This Time It's Different? Youth Labour Markets during “The Great Recession”. Comparative Economic Studies, 3, 395-412.

Oi, W.Y., 1962, "Labor as a Quasi-Fixed Factor,” Journal of Political Economy, Vol. 70, pp. 538 .

Pastore F. (2014), The Youth Experience Gap. A classification of school-to-work transition regimes, Working Paper.

Perugini, C. and Marcello Signorelli (2004) "Employment Performance and Convergence in the European Countries and Regions" The European Journal of Comparative Economics [1824-2979] 2004 vol:1 iss:2 pg:243

Perugini, C. and Marcello Signorelli (2007) "Labour market performance differentials and dynamics in EU-15 countries and regions" The European Journal of Comparative Economics 2007 Vol. 1 (2) pg:243

Quintini G. and Manfredi T. (2009), "Going Separate Ways? School-to-Work Transitions in the United States and Europe", OECD Social, Employment and Migration Working Paper, 90.

Ryan P. (2001). The School-to-Work Transition: A Cross-National Perspective. Journal of Economic Literature, 39, 1, 34-92.

Sargent T. and Ljundqvist L. (1995), The European Unemployment Dilemma", WP 95-17, Federal Reserve Bank of Chicago.

Scarpetta S., Sonnet A. and Manfredi T. (2010), "Rising Youth Unemployment During the Crisis: How to Prevent Negative Long-term Consequences on a Generation?", OECD Social, Employment and Migration Working Papers, 6.

Signorelli Marcello, Misbah Choudhry and Enrico Marelli (2012), "The Impact of Financial Crises on the Female Labour", The European Journal of Development Research, 3.

Solow R.M. (2000), Unemployment in the United States and in Europe: A Contrast and the Reasons, CESifo Working Paper. 
Wasmer, Etienne, and Philippe Weil, 2004, \The Macroeconomics of Labor and Credit Market Imperfections," American Economic Review (American Economic Association), 94(4): 944-63.

Verick S. (2009), "Who is Hit Hardest During a Financial Crisis? The Vulnerability of Young Men and Women to Unemployment in an Economic Downturn”, IZA Discussion Papers, 4359.

World Bank (2010), Global Economic Prospects. 2010 Foresees Long Road to Economic Recovery, Washington. 


\section{Appendix}

Figure A1: Unemployment rate by Country, all population
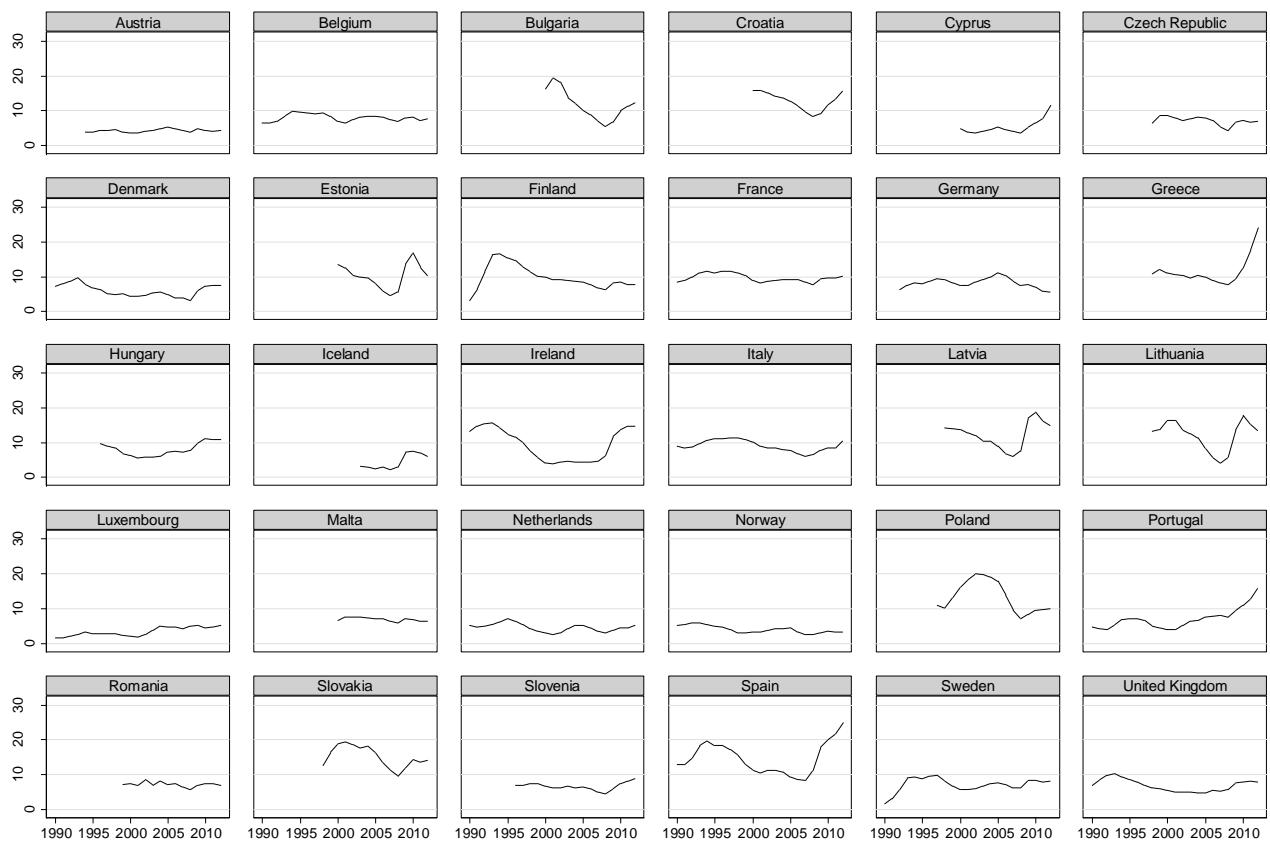

Year

Graphs by Country

Figure A2: Youth Unemployment rate by Country
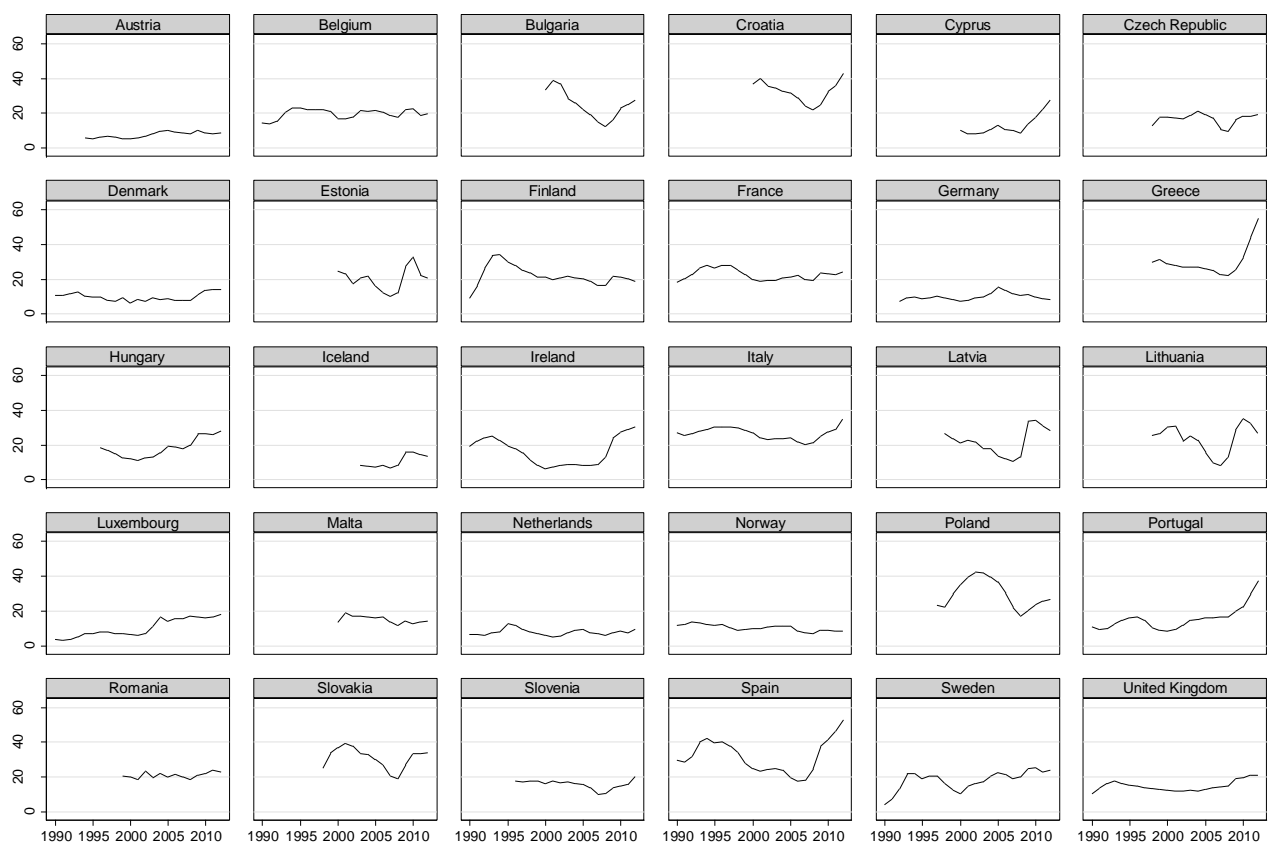

Graphs by Country

Year 
Figure A3: Crisis Severity by Country

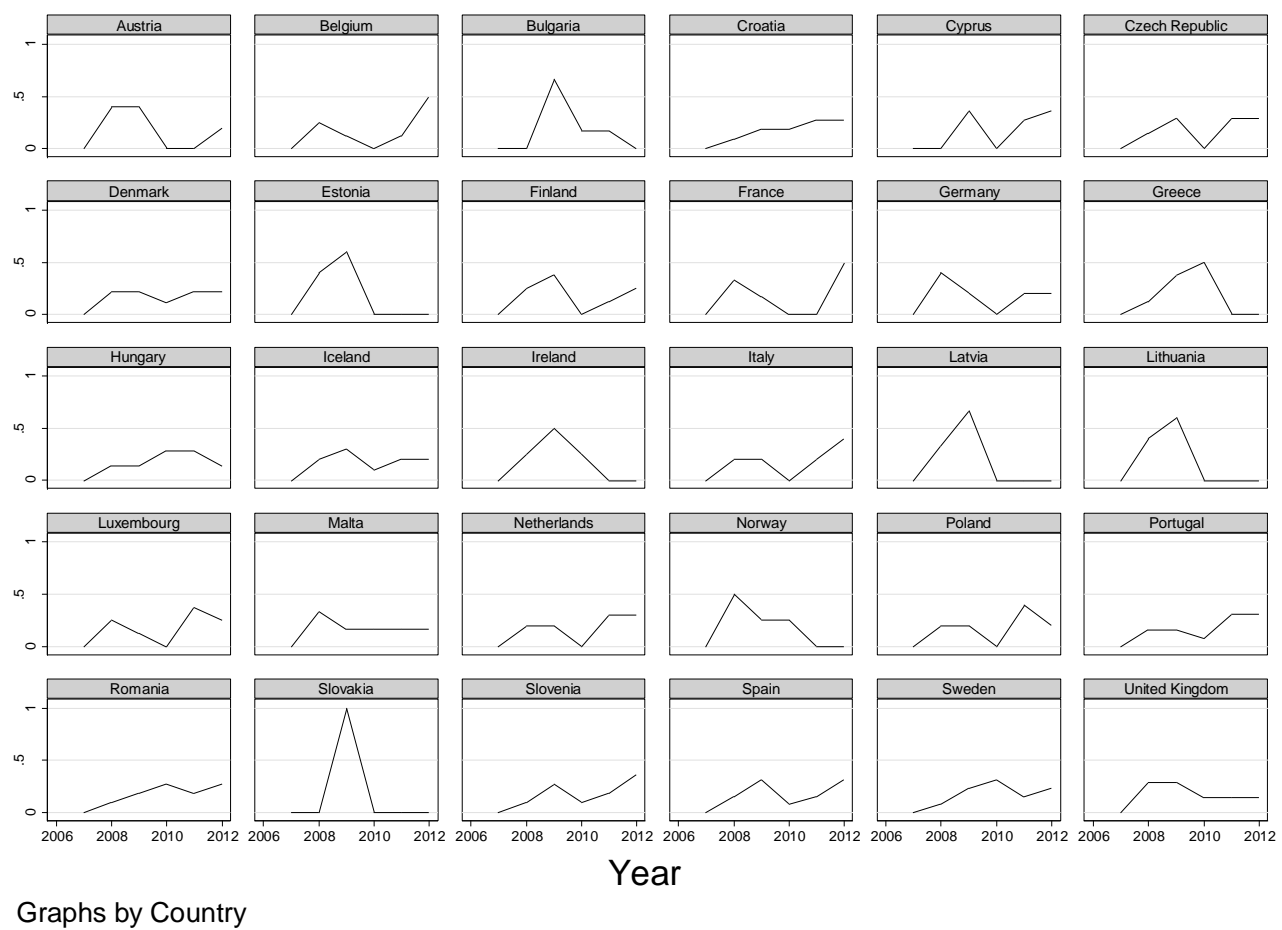

Table A1: Detailed Variables Description

Name of the Variable

Description

Source

GDP

gdp

GDP at market prices, millions of Euros (ECU until 1998)

gdppc

GDP per inhabitant in Euros at current market prices

quarterly_gdp

Quarterly GDP at current market prices, seasonally adjusted

Eurostat, Quarterly National Accounts

Eurostat, National Accounts and GDP

Eurostat, National Accounts and GDP

Unemployment

Total Unemployment

Unemployment rate, all population

Eurostat, Labour Market Statistics

Youth Unemployment

Unemployment rate of people aged under 25 , \% of total labour force

Eurostat, Labour Market Statistics

Labour Market Policies (LMP)

totlmp

Labour market policy public expenditure in \% of GDP

Eurostat, Labour Market Statistics

almp

active Imp, total, in \% GDP

Eurostat, Labour Market Statistics 
plmp

train2

rot3

emplinc4

rehab5

jobcr6

stup7

eret8

outwork9

Opportunity cost of being employed

Total LMP

Active LMP

Passive LMP

Training passive Imp, total, in \% GDP

active Imp, training; Millions of Euros and annual stock (i.e. average people involved)

active Imp, job rotation and job sharing, Millions of Euros and annual stock (i.e. average people involved) active Imp, employment incentives; Millions of Euros and annual stock (i.e. average people involved)

active Imp, supported employment and rehabilitation; Millions of Euros and annual stock

active Imp, direct job creation; Millions of Euros and annual stock (i.e. average people involved)

active Imp, start-up incentives; Millions Euro and annual stock (i.e. average people involved)

passive Imp, early retirement; Millions of Euros and annual stock (i.e. average people involved)

passive Imp, out of work and maintenance; Millions of Euros and annual stock
Eurostat, Labour Market Statistics

Eurostat, Labour Market

Statistics

Eurostat, Labour Market Statistics

Eurostat, Labour Market Statistics

Eurostat, Labour Market Statistics

Eurostat, Labour Market Statistics

Eurostat, Labour Market Statistics

Eurostat, Labour Market Statistics

Eurostat, Labour Market Statistics

own calculations

vs. average totlmp beneficiary:

(totlmp in Euro/totlmp

beneficiaries)/gdppc

opportunity cost of being employed vs. average almp beneficiary: (almp in Euro/almp beneficiaries)/gdppc

opportunity cost of being employed vs. average plmp beneficiary: (almp in Euro/plmp beneficiaries)/gdppc

opportunity cost of being employed vs. training beneficiary: (train2 in Euro/train2 beneficiaries)/gdppc own calculations

own calculations

\section{own calculations}

\section{own calculations}


Job Rotation

Employment Incentives

Rehabilitation

Job Creation

Start-up Incentives

Early Retirement

Out of work and maintenance

\section{Crisis}

bc2008

bc2007

qdrops

countrydrops

Crisis

Interaction Terms

Policy*Crisis opportunity cost of being employed

own calculations

vs. training beneficiary: (rot3 in

Euro/rot3 beneficiaries)/gdppc

opportunity cost of being employed vs. employment

beneficiary:(emplinc4 in

Euro/emplinc4 beneficiaries)/gdppc

opportunity cost of being employed vs. rehabilitation beneficiary:

(rehab5 in Euro/rehab5

beneficiaries)/gdppc

opportunity cost of being employed vs. job creation beneficiary: (jobcr6 in Euro/jobcr6 beneficiaries)/gdppc opportunity cost of being employed vs. start-up beneficiary: (stup7 in Euro/stup7 beneficiaries)/gdppc

opportunity cost of being employed vs. early retirement beneficiary:

(eret8 in Euro/eret8

beneficiaries)/gdppc

opportunity cost of being employed vs. out of work beneficiary:

(outwork9 in Euro/outwork9

beneficiaries)/gdppc

banking crisis started in 2008

banking crisis started in 2007

country and year specific number of quarters of negative GDP growth, from crisis beginning country specific total number of qdrops between 2008-2012

country-year specific severity of the crisis: qdrops/countrydrops

opportunity cost of being employed* crisis, e.g.

ratio_totlmp_on_gdppc*countrysev

own calculations own calculations

own calculations

own calculations

own calculations

own calculations

own calculations

Laeven and Valencia (2010, 2012)

Laeven and Valencia (2010, 2012)

own calculations

own calculations

own calculations, one policy specific interaction term for each of the listed labour market policies has been calculated 